\title{
Diversity and Seasonal Fluctuations of Arthropod Fauna in Bangladesh Deepwater Rice
}

\author{
David Catling ${ }^{1}$ and Zahirul Islam*2
}

\begin{abstract}
An intensive study of the diversity of arthropod fauna in Bangladesh deepwater rice ecosystem from 1977 to 1980 revealed: 139 phytophages, 75 predators, 75 parasitoids and 44 scavengers identified to species level. Adding those forms identified to family/subfamily brought the total to 375 species. Insecta comprised 354 species belonging to more than 100 families. This is a conservative estimate since the main sampling methods used, sweepnetting and the rearing of parasitoids, is fairly effective for mid- and upper canopy forms, but is not effective for collecting fauna in the benthos, neuston and lower plant canopy for which a suction sampler is necessary.There was a marked seasonal fluctuation in numbers and composition of the fauna due mainly to the nature of the deepwater rice plant and the annual flooding pattern. The preflood period was conducive to moderate buildups of some canopy-living insects. In the flooding period the numbers of many arthropods crashed precipitously and never recovered (eg leafhoppers and planthoppers). Those forms adapted to deep flooding continued at moderate levels (eg acridids, green leafhopper), while a few arthropods were able to increase their numbers (eg tettigonids, yellow stem borer and spiders). Spiders, the most abundant predator group, were numerous at all times even during deep flooding and they probably limited the numbers of leafhoppers, planthoppers and some other pests. In addition, 75 parasitoids formed part of the faunal community and attacked many phytophages.
\end{abstract}

Key words: Phytophages, predators, parasitoids, population fluctuations, floating rice

\section{INTRODUCTION}

This paper presents the results of an intensive field survey of the arthropod fauna in the major deepwater rice areas of Bangladesh carried out over a three-year period in the late 1970s when deepwater rice was grown on more than two million hectares. This was the first time that the fauna of deepwater rice was systematically studied anywhere in Asia, and new field methods were developed to work in this deeply flooded environment. It is unlikely that such a study will be repeated. Deepwater rice refers to the broadcast aman crop of 'elongating' or 'floating rices' grown at water depths of $>100 \mathrm{~cm}$ for one month or longer, and the transplant aman crop of 'traditional tall' cultivars grown at water depths of 50-100 $\mathrm{cm}$. This is a traditional rice agroecosystem of great antiquity where insecticides are rarely applied.

The results of this survey were first described in an unpublished report (Catling, 1980). The most important findings, particularly those of economic interest, were subsequently published in a series of papers by Catling and Islam from 1982 to 1995, and in a book by Catling (1992). Despite these publications, significant findings in this original study have remained unpublished and largely overlooked. Moreover, there is increasing interest in the invertebrate fauna of rice as shown by the recent review of this subject by FAO and IRRI (Islam et al., 2012).

\footnotetext{
${ }^{1}$ Consultant in Agriculture and Development. 4 Acorn Close, Vredehoek, Cape Town 8001, South Africa.

${ }^{2}$ Freelance Wildlife Researcher. 61 Coleman Avenue, Toronto, Ontario M4C1P8, Canada.

*Corresponding authors' email: zislam51@yahoo.ca
} 
The Bangladesh study concentrated on the arthropods, mostly insects, that make up the fauna of the deepwater rice ecosystem. The study was primarily designed to reveal the recognized rice pests and their natural enemies, and to indicate other arthropods or invertebrates that might be potential pests of deepwater rice. Less attention was paid to aquatic organisms living in the neuston (at the water surface), the benthos (the soil surface of the flooded field), and the plankton and nekton. The seasonal population fluctuations of the fauna were also investigated.

\section{MATERIALS AND METHODS}

An intensive survey of farmers' deepwater rice fields was carried out in 1977 and 1978, with observations on main pests continuing during the 1979 deepwater rice season. The crescentshaped area where most deepwater rice is grown falls within three main zones based on a hydrogeologic classification of Bangladesh: the Lower Ganges plus active Ganges floodplain, the Lower Jamuna plus active Brahmaputra-Jamuna floodplains, and the Old Meghna Estuarine plus Middle Meghna floodplains (Figure 1.). The simple field collection equipment consisted of sweepnets, quadrats for direct field counts, small knives for dissecting plants for stem borers, battery operated light trap, glass jars for using as pit-fall trap, and freshwater net for sampling aquatic fauna were used.

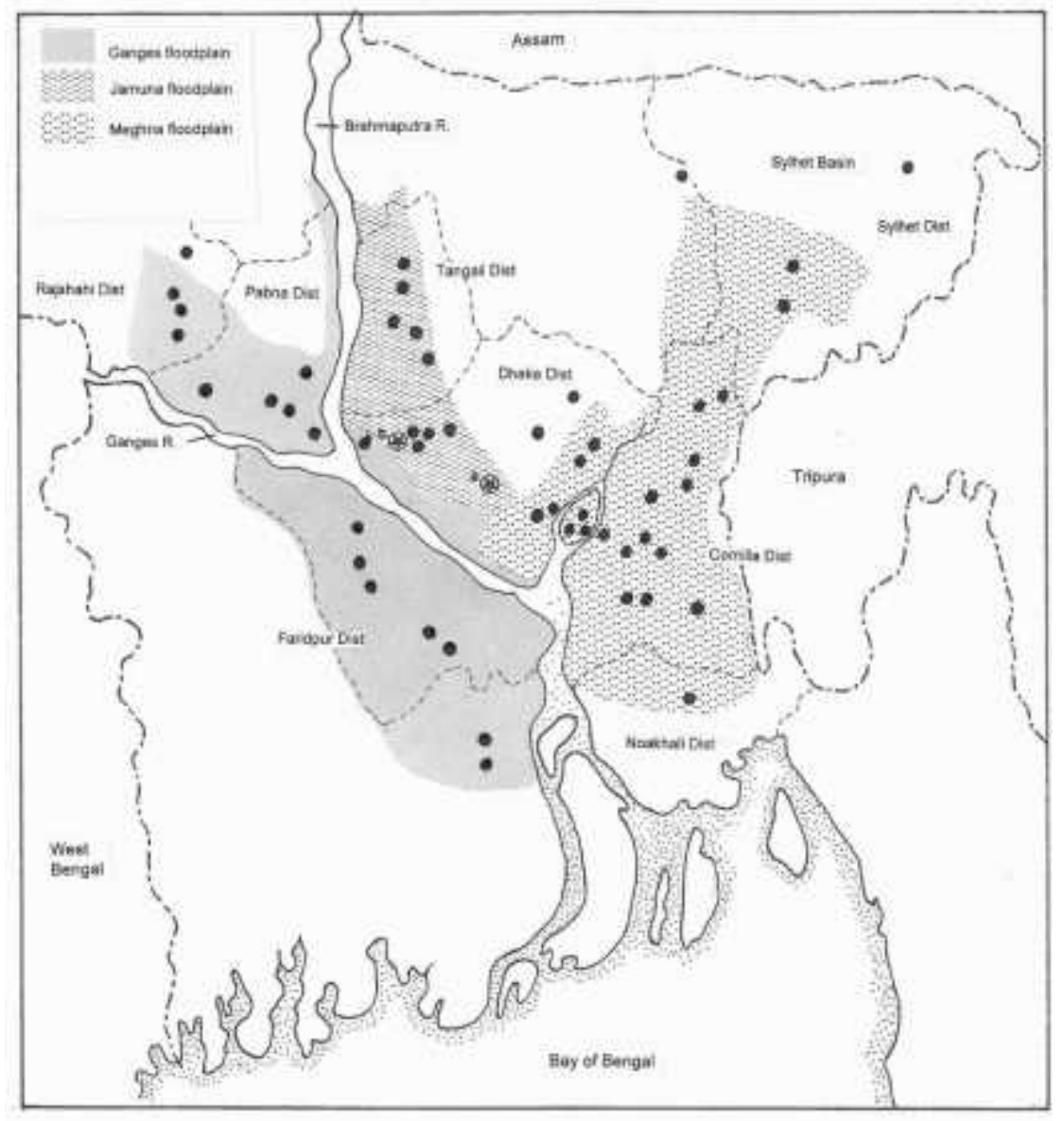

Fig. 1. Main survey sites according to the three main hydrogeologic zones where most deepwater rice is grown, Bangladesh, 1977 and 1978. Additional study sites are shown by asterisks: Agrakhola village (a) and Bastia village (b). 


\section{Field sites}

Sample fields having good access from roads and waterways were selected systematically in each floodplain for the main survey (Figure 1). Of these, 10 'sequential sites' were selected to investigate differences between years. Two survey trips were made to the scattered deepwater rice fields in the remote Sylhet Basin by flying boat. Additional data were collected on arthropod incidence and plant injury at Agrakhola village under Keraniganj, Dhaka, sampled every 1-2 weeks in 1977 and 1978 (Figure 1), together with daily records of water depth. Similar observations were made in another farmer's field at a village under Bastia of Manikganj district. During the 1977-78 rabi (dry) season, sweeps and direct counts were carried out at the 10 sequential sites and at Agrakhola, on deepwater rice crop residues and rabi crops (consisting mainly of wheat and pulses).

\section{Direct counts}

In each sample field, 2-3 observers examined the plants for insects and plant injury along the diagonals for 20-30 minutes. Leaf damage, deadhearts, whiteheads and other injury symptoms were examined to determine the pest species, the age class present or the causal organism. Where significant damage was evident, a wooden quadrat $(50 \times 50 \mathrm{~cm}$, area 0.25 $\mathrm{m}^{2}$ ) was used to estimate the extent of damage in a total area of 3-4 $\mathrm{m}^{2}$. With flood inundation observations were initially made from a standing position in the water; in deeper water the observations were made from the side of a boat. Insects were hand-collected and taken to the laboratory for identification. At Agrakhola, overwintering larvae were counted beneath the dry stubble using a wooden quadrat (area $4 \mathrm{~m}^{2}$ ). Since Lepidoptera are not taken effectively in sweeps, their incidence was mainly assessed from the in situ field observations of larval stages and vegetative damage. Table 1 shows the numbers of direct counts made in 1977 and 1978.

\section{Sweepneting}

This was the main method for assessing the numbers of most non-boring insects living in the plant canopy. Sweeps were taken with a $30 \mathrm{~cm}$ diameter net, with detachable bottom section, along the field diagonals in $1.5 \mathrm{~m}$ arcs, usually in mid morning by one of the same two operators. In flooded fields, sweeping from a crouching position over the bows of a boat as it glides slowly through the water was fairly efficient until impeded by the dense mass of floating stems by September. With flood inundation, local country boats were hired from farmers for most field sampling, or an inflatable boat was used. During the ripening period, when most rice plants are prostrate, sweeping was concentrated on the remaining erect plants (probably resulting in disproportionately large numbers for some faunal groups). Initially 20-40 single sweeps were taken in each field but this was later increased to 60 single sweeps/field. Table 1 shows the numbers of sweepnet samples taken in 1977 and 1978.

\section{Stem dissections}

Methods for assessing stem borers and other boring insects were described in Catling, et al., 1984-85. A minimum of 100 stems were removed systematically along the diagonals of each sample field from the start of elongation to ripening stage. Each individual stem was split open along the whole length using a knife or the thumbnail to expose the developing stages and internal plant damage. 


\section{Rearing of insects}

The immature stages of insects from the direct counts and stem dissections were reared in the insectary to obtain the adult forms and emergent parasitoids using standard methods.

\section{Light trap and pitfall traps at Agrakhola}

An Etech light trap (Texas design) powered by a car battery was operated nightly from February 1977 to March 1980 and again from July to November 1980. During the flooding period the trap was placed in a small boat to ensure a constant height above the rice canopy. The light trap was operated from sunset to $21: 00 \mathrm{hr}$ and the very large catches from July to October 1977 were sub-sampled. Pitfall traps were used from February to May 1978 to trap ground-running predators such as carabid beetles, crickets and earwigs. A typical freshwater net was used to take faunal samples $50 \mathrm{~cm}$ below the water surface in July and September 1978.

\section{Identification of fauna}

All of the recognized pest species, plus all reared material, conspicuous predators and other arthropod species occurring in large numbers were sent to specialist taxonomists for identification. A large proportion of the hymenopterous material from the sweeps was first bulked into categories according to year, floodplain and flooding period, and then identified down to family, genus and in some cases to species. Similarly most of the Diptera caught in the sweeps was bulked and identified to family level only. The four main dipterous pests producing recognizable injury symptoms, and 10 other potentially economic species were identified to genus and species. In addition, several parasitoids were reared from rice pests. The main parasitoid groups from the bulked sweepnet material, and those species reared from insect hosts, were mostly identified by taxonomists at the Commonwealth Institute of Entomology in London and Bangalore.

\section{Treatment of field data}

The numbers of sweeps and direct counts were approximately proportional to the area of each floodplain. Arthropod activity and pest damage were analyzed according to the five flood periods within the deepwater rice season (Table 1) and also by floodplain and year. A more critical comparison between years was made at the 10 sequential sites. Data from the Agrakhola site, where observations were made at more frequent intervals, are sometimes reported in detail. Data from the 268 sweepnet samples and 280 direct field counts were expressed as: (i) the mean numbers of arthropods/100 single sweeps and (ii) the number of 'population buildups' exceeding specified thresholds of: $>25 / 100$ sweeps for large predators, hispa beetle; $>50 / 100$ single sweeps for Orthoptera, thrips, smaller predators; $>100 / 100$ sweeps for leafhoppers and planthoppers; >200/100 single sweeps for the minute flea beetle. The threshold for leafeaters was $>10 \%$ damaged leaves.

Table 1. Numbers of samples taken in main surveys of deepwater rice fields according to flood period and rice growth stage, Bangladesh, 1977-78

\begin{tabular}{|l|l|c|c|c|c|}
\hline Flood period & Rice growth & \multicolumn{2}{|c|}{ Sweepnets } & \multicolumn{2}{|c|}{ Direct counts } \\
& stage & $\mathbf{1 9 7 7}$ & $\mathbf{1 9 7 8}$ & $\mathbf{1 9 7 7}$ & $\mathbf{1 9 7 8}$ \\
\hline 1. Preflood & Seedling & 42 & 11 & 43 & 11 \\
2. Preflood & Basal tillering & 27 & 25 & 26 & 25 \\
3. Flood: >20 cm to end July & Elongation & 34 & 15 & 36 & 15 \\
4. Flood: Aug to Sep 20 & Elongation, & 33 & 25 & 35 & 25 \\
5. Flood receding: Sep 21 to early & nodal tillering & 31 & 25 & 37 & 27 \\
Dec & Flowering, & & & & \\
& ripening & & & & \\
\hline
\end{tabular}




\section{RESULTS}

The fauna is divided into four recognized guilds: phytophages, predators, parasitoids and scavengers.

\section{Phytophages}

This, the largest guild, consisted of 139 species comprising sex insect orders, five Nematoda, one crustacean and one mollusc (Table 2).

Table 2. Checklist of fauna classified as phytophages in deepwater rice, Bangladesh, 1977-80. Compiled from sweepnet catches, hand collection, reared in insectary, light trap catches, pitfall traps and underwater net. Rice pests as recognized by Grist and Lever (1969) and/or Reissig et al (1986)

\begin{tabular}{|c|c|c|c|c|}
\hline Taxon & Scientific name & Family & Common name & Rice pest \\
\hline Nematoda & $\begin{array}{l}\text { Aphelenchoides besseyi Christie } \\
\text { Ditylenchus angustus (Butler) } \\
\text { Filipjev } \\
\text { Hirschmanniella oryzae (Breda de } \\
\text { Haan) } \\
\text { Meloidogyne graminicola Golden and } \\
\text { Birchfield } \\
\text { Tylenchorhynchus martini Fielding }\end{array}$ & & $\begin{array}{l}\text { White tip } \\
\text { nematode } \\
\text { Ufra or stem } \\
\text { nematode } \\
\text { Root nematode } \\
\text { Root-knot } \\
\text { nematode }\end{array}$ & $\begin{array}{l}+ \\
+ \\
+ \\
+\end{array}$ \\
\hline Crustacea & Sartoriana spinigera (Wood-Mason) & Gecarcinucidae & crab & + \\
\hline $\begin{array}{l}\text { Insecta } \\
\text { Orthoptera }\end{array}$ & $\begin{array}{l}\text { Acrida exaltata Walker } \\
\text { Aiolopus thalassinus tamulus (F.) } \\
\text { Atractomorpha crenulata crenulata } \\
\text { (Fabr.) } \\
\text { Atractomorpha psittacina (de Haan) } \\
\text { Conocephalus longipennis (de Haan) } \\
\text { Euconocephalus ?incertus (Walker) } \\
\text { Euscyrtus concinnus de Haan } \\
\text { Gesonula punctifrons Stål } \\
\text { Gryllotalpa africana P. de Beauv. } \\
\text { Modicogryllus ?confirmatus (Walker) } \\
\text { Oxya velox (F.) } \\
\text { Oxya hyla intricata Stål } \\
\text { Oxya japonica japonica (Thunb.) } \\
\text { Pusana levis Uvarov } \\
\text { Trilophidia annulata (Thunb.) }\end{array}$ & $\begin{array}{l}\text { Acrididae } \\
\text { Acrididae } \\
\text { Pyrgomorphidae } \\
\text { Pyrgomorphidae } \\
\text { Tettigoniidae } \\
\text { Tettigoniidae } \\
\text { Gryllidae } \\
\text { Acrididae } \\
\text { Gryllotalpidae } \\
\text { Gryllidae } \\
\text { Acrididae } \\
\text { Acrididae } \\
\text { Acrididae } \\
\text { Tettigoniidae } \\
\text { Acrididae }\end{array}$ & $\begin{array}{l}\text { Long-horned } \\
\text { field cricket } \\
\text { Mole cricket } \\
\text { Paddy rice } \\
\text { grasshopper } \\
\text { Paddy rice } \\
\text { grasshopper } \\
\text { Paddy rice } \\
\text { grasshopper }\end{array}$ & $\begin{array}{l}+ \\
+ \\
+ \\
+ \\
+ \\
+ \\
+ \\
+ \\
+ \\
+ \\
+ \\
+ \\
+\end{array}$ \\
\hline
\end{tabular}




\begin{tabular}{|c|c|c|c|c|}
\hline $\begin{array}{l}\text { Hemiptera } \\
\text { Homoptera }\end{array}$ & 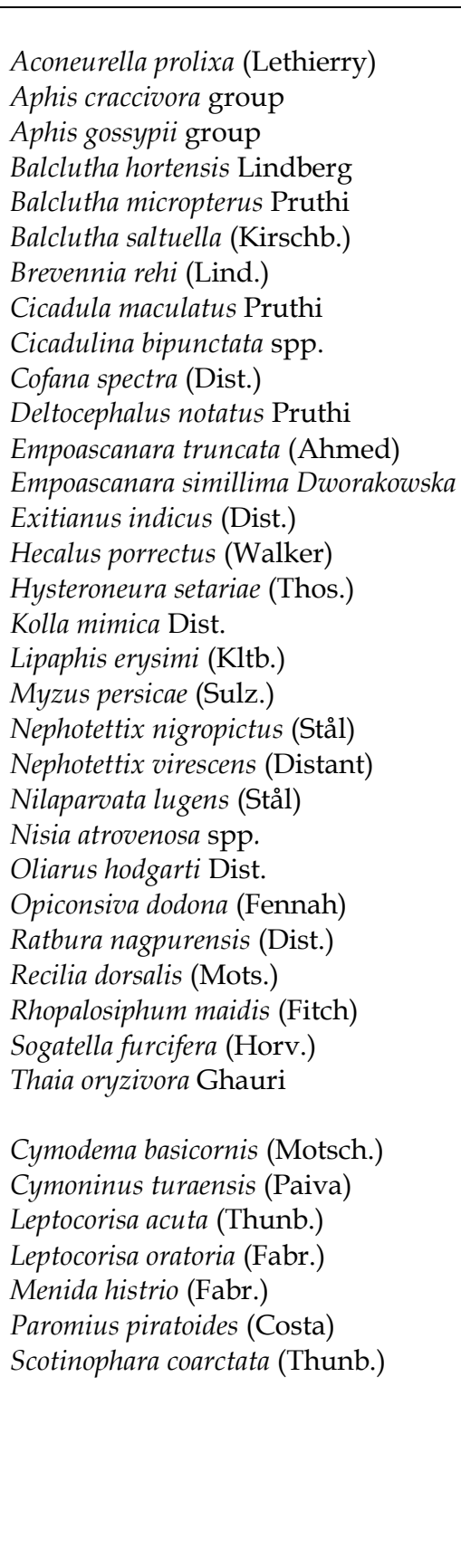 & $\begin{array}{l}\text { Jassidae } \\
\text { Aphididae } \\
\text { Aphididae } \\
\text { Jassidae } \\
\text { Jassidae } \\
\text { Jassidae } \\
\text { Coccidae } \\
\text { Jassidae } \\
\text { Jassidae } \\
\text { Jassidae } \\
\text { Jassidae } \\
\text { Jassidae } \\
\text { Jassidae } \\
\text { Jassidae } \\
\text { Jassidae } \\
\text { Aphididae } \\
\text { Jassidae } \\
\text { Aphididae } \\
\text { Aphididae } \\
\text { Jassidae } \\
\text { Jassidae } \\
\text { Delphacidae } \\
\text { Meenoplidae } \\
\text { Cixiidae } \\
\text { Delphacidae } \\
\text { Jassidae } \\
\text { Jassidae } \\
\text { Aphididae } \\
\text { Delphacidae } \\
\text { Jassidae } \\
\text { Lygaeidae } \\
\text { Coreidae } \\
\text { Alydidae } \\
\text { Alydidae } \\
\text { Pentatomidae } \\
\text { Lygaeidae } \\
\text { Pentatomidae }\end{array}$ & $\begin{array}{l}\text { Mealy bug } \\
\text { Rice white } \\
\text { leafhopper } \\
\\
\text { Rice green } \\
\text { leafhopper } \\
\text { Rice brown } \\
\text { planthopper } \\
\text { lice green } \\
\text { Ricepper } \\
\text { Rice seed bug } \\
\text { Rice seed bug } \\
\text { Ear-headed } \\
\text { shield bug } \\
\text { Rice black bug } \\
\text { leafhopper } \\
\text { Planthopper } \\
\text { Rice zigzag } \\
\text { leafhopper } \\
\\
\text { Rice whitebacked } \\
\text { lange }\end{array}$ & $\begin{array}{l}+ \\
+ \\
+ \\
+\end{array}$ \\
\hline Thysanoptera & $\begin{array}{l}\text { Chloethrips oryzae (Wills) } \\
\text { Frankliniella sp. } \\
\text { Haplothrips sp. } \\
\text { Podothrips oryzae (Wills) } \\
\text { Stenchaetothrips biformis (Bagnall) }\end{array}$ & $\begin{array}{l}\text { Thripidae } \\
\text { Thripidae } \\
\text { Phlaeothripidae } \\
\text { Phlaeothripidae } \\
\text { Thripidae }\end{array}$ & $\begin{array}{l}\text { Rice thrips } \\
\text { Rice thrips }\end{array}$ & $\begin{array}{l}+ \\
+ \\
+ \\
+ \\
+\end{array}$ \\
\hline Lepidoptera & $\begin{array}{l}\text { Agrotis ipsilon Hufn. } \\
\text { Chilo polychrysus (Meyrick) } \\
\text { Chrysodeixis chalcites Esp. } \\
\text { Chrysodeixis eriosoma Dbldy. } \\
\text { Cnaphalocrocis medinalis Guen. } \\
\text { Creatonotos gangis L. } \\
\text { Diachrysia orichalcea F. }\end{array}$ & $\begin{array}{l}\text { Noctuidae } \\
\text { Pyralidae } \\
\text { Noctuidae } \\
\text { Noctuidae } \\
\text { Pyralidae } \\
\text { Arctiidae } \\
\text { Noctuidae }\end{array}$ & $\begin{array}{l}\text { Greasy cutworm } \\
\text { Dark-headed } \\
\text { stem borer } \\
\text { Rice leaffolder }\end{array}$ & $\begin{array}{l}+ \\
+\end{array}$ \\
\hline
\end{tabular}




\begin{tabular}{|c|c|c|c|c|}
\hline & $\begin{array}{l}\text { Elydna erigida Swinh. } \\
\text { Heliothis armigera Hb. } \\
\text { Melanitis lede ismene Cramer } \\
\text { Mythimna separata Walker } \\
\text { Naranga diffusa Walker } \\
\text { Naranga aenescens Moore } \\
\text { Nymphula affinialis Gn. } \\
\text { Nymphula depunctalis (Guen.) } \\
\text { Pelopidas agna Moore } \\
\text { Psalis pennatula F. } \\
\text { Scirpophaga excerptalis (Walker) } \\
\text { Scirpophaga fusciflua Hamps. } \\
\text { Scirpophaga incertulas (Walker) } \\
\text { Scirpophaga nivella (Fabr.) } \\
\text { Scirpophaga virginia Schultze } \\
\text { Sesamia inferens (Walker) } \\
\text { Spodoptera cilium Gn. } \\
\text { Spodoptera litura F. } \\
\text { Spodoptera mauritia Boisd. }\end{array}$ & $\begin{array}{l}\text { Noctuidae } \\
\text { Noctuidae } \\
\text { Satyridae } \\
\text { Noctuidae } \\
\text { Noctuidae } \\
\text { Noctuidae } \\
\text { Pyralidae } \\
\text { Pyralidae } \\
\text { Hesperiidae } \\
\text { Lymantriidae } \\
\text { Pyralidae } \\
\text { Pyralidae } \\
\text { Pyralidae } \\
\text { Pyralidae } \\
\text { Pyralidae } \\
\text { Noctuidae } \\
\text { Noctuidae } \\
\text { Noctuidae } \\
\text { Noctuidae }\end{array}$ & $\begin{array}{l}\text { American } \\
\text { bollworm } \\
\text { Rice butterfly } \\
\text { Rice ear-cutting } \\
\text { caterpillar } \\
\text { Rice green } \\
\text { semilooper } \\
\text { Rice caseworm } \\
\text { Rice skipper } \\
\text { Rice hairy } \\
\text { caterpillar } \\
\\
\text { Yellow stem } \\
\text { borer } \\
\text { Pink stem borer } \\
\text { Common } \\
\text { cutworm } \\
\text { Rice swarming } \\
\text { caterpillar }\end{array}$ & $\begin{array}{l}+ \\
+ \\
+ \\
+ \\
+ \\
+ \\
+ \\
+\end{array}$ \\
\hline Diptera & $\begin{array}{l}\text { Atherigona oryzae Malloch } \\
\text { Atherigona falcata (Thomson) } \\
\text { Atherigona reversura Villeneuve } \\
\text { Chlorops ?antennatus } \\
\text { Chlorops ?minima Becker } \\
\text { Hydrellia philippina Ferino } \\
\text { Oscinella } 2 \text { spp. } \\
\text { Orseolia oryzae (Wood-Mason) } \\
\text { Pachylophus rufescens (de Meijere) } \\
\text { Pseudonapomyza nr asiatica (Spencer) }\end{array}$ & $\begin{array}{l}\text { Muscidae } \\
\text { Muscidae } \\
\text { Muscidae } \\
\text { Chloropidae } \\
\text { Chloropidae } \\
\text { Ephydridae } \\
\text { Chloropidae } \\
\text { Cecidomyiidae } \\
\text { Chloropidae } \\
\text { Agromyzidae }\end{array}$ & $\begin{array}{l}\text { Seedling maggot } \\
\text { Rice whorl } \\
\text { maggot } \\
\text { Rice gall midge } \\
\text { Leaf miner }\end{array}$ & $\begin{array}{l}+ \\
+\end{array}$ \\
\hline Coleoptera & $\begin{array}{l}\text { Altica caerulea Oliv. } \\
\text { Altica } 5 \text { spp. } \\
\text { Apion benignum Faust } \\
\text { Apion corchori Mshl. } \\
\text { Apion tumidum Gerst. } \\
\text { Bagous humeridens Hust. } \\
\text { Bagous nr humeridus Hust. } \\
\text { Bagous sumatrensis Faust } \\
\text { Blosyrus asellus (Oliv.) } \\
\text { Bruchidius sp. } \\
\text { Bruchus pisorum L. } \\
\text { Callosobruchus chinensis (F.) } \\
\text { Cassida nigriventris Boh. } \\
\text { Chaetocnema basalis Baly } \\
\text { Dicladispa armigera Ol. } \\
\text { Formicomus mutillarius (Saund.) } \\
\text { Formicomus antiquus Krek. } \\
\text { Hedychrous rufofasciatus Mshl. } \\
\text { Hydronomidius molitor Faust } \\
\text { Hydronomus } 2 \text { spp. } \\
\text { Lema rufofrontalis Jacoby } \\
\text { Monolepta signata Ol. } \\
\text { Myllocerus blandus Faust }\end{array}$ & $\begin{array}{l}\text { Chrysomelidae } \\
\text { Chrysomelidae } \\
\text { Apionidae } \\
\text { Apionidae } \\
\text { Apionidae } \\
\text { Curculionidae } \\
\text { Curculionidae } \\
\text { Curculionidae } \\
\text { Cuculionidae } \\
\text { Bruchidae } \\
\text { Bruchidae } \\
\text { Bruchidae } \\
\text { Chrysomelidae } \\
\text { Chrysomelidae } \\
\text { Chrysomelidae } \\
\text { Anthicidae } \\
\text { Anthicidae } \\
\text { Curculionidae } \\
\text { Curculionidae } \\
\text { Curculionidae } \\
\text { Chrysomelidae } \\
\text { Chrysomelidae } \\
\text { Curculionidae }\end{array}$ & $\begin{array}{l}\text { Flea beetle } \\
\text { Rice hispa } \\
\text { Root weevil } \\
\text { White spotted } \\
\text { flea beetle }\end{array}$ & $\begin{array}{l}+ \\
+\end{array}$ \\
\hline
\end{tabular}




\begin{tabular}{|l|l|l|l|l|}
\hline & Nanophyes nigritulus Boh. & Apionidae & \\
& Nanophyes 3 spp. & Apionidae & \\
& Pachnephorus bretinghami Baly & Chrysomelidae & \\
& Rhicnostomus terrenus Mshl & Curculionidae & & \\
& Sitona crinita (Herbst) & Curculionidae & Root weevil & \\
& Stilbus albomaculatus Mots. & Phalacridae & & \\
& Stilbus curvolineatus Champ. & Phalacridae & & \\
& Tanymecus indicus Faust & Curculionidae & Gujhia weevil & + \\
\hline Mollusca & Pila pesmei (Morlet) & Pilidae & & + \\
\hline
\end{tabular}

\section{Orthoptera}

The 15 species belong to five families, of which 12 are regarded as rice pests (Table 2). In addition, two unidentified Tetrigidae (grouse-locusts) occurred in small numbers in the preflood and flood receding period. During the rabi season two unknown forms occurred, a tridactyloid (pigmy mole cricket) in pre- and postflood periods, and a phaneropterinid.

Table 3. Seasonal incidence of insects in sweeps from surveys of deepwater rice, Bangladesh, $1977+1978$, in mean numbers $/ 100$ sweeps unless otherwise stated

\begin{tabular}{|c|c|c|c|c|c|c|c|}
\hline \multirow{2}{*}{ Insect } & \multicolumn{2}{|c|}{ Preflood } & \multicolumn{2}{|c|}{ Flooding } & \multirow{2}{*}{$\begin{array}{c}\begin{array}{c}\text { Flood } \\
\text { receding }\end{array} \\
5\end{array}$} & \multirow{2}{*}{$\begin{array}{l}\text { Population } \\
\text { buildups } \\
\text { (no.) }\end{array}$} & \multirow{2}{*}{$\begin{array}{c}\text { Outbreaks } \\
\text { (no.) }\end{array}$} \\
\hline & 1 & 2 & 3 & 4 & & & \\
\hline \multicolumn{8}{|l|}{ Phytophages } \\
\hline Acridid leafeaters & 4.6 & 13.8 & 4.3 & 3.3 & 5.2 & 3 & 0 \\
\hline Tettigoniids + gryllids & 0.8 & 0.7 & 3.7 & 4.2 & 41.9 & 16 & 0 \\
\hline Green leafhoppers** & - & 10 & - & 11 & 31 & 11 & 0 \\
\hline Orange leafhopper** & - & 1 & - & 1 & 51 & 1 & 0 \\
\hline Whitebacked planthopper** & - & 25 & - & 4 & 4 & 8 & 0 \\
\hline Rice seed bugs & 0.9 & 5.6 & 0.4 & 0.4 & 1.2 & 1 & 0 \\
\hline Thrips (several spp.) & 8 & 58 & 13 & 4 & 6 & 16 & 5 \\
\hline Leaffolder* & 25 & 76 & 84 & 81 & 65 & - & 7 \\
\hline Rice hispa & 1.4 & 17.5 & 1.3 & 0.6 & 1.4 & 5 & 5 \\
\hline Flea beetle & 526 & 263 & 5 & 5 & 1 & 25 & 17 \\
\hline Tanymecus indicus & 0.4 & 3.8 & 0.3 & 0.7 & 0.2 & 1 & 0 \\
\hline Curculionidae + Apionidae & 0.4 & 2 & 0.6 & 0.8 & 0.7 & 0 & 0 \\
\hline Stilbus curvolineatus & 18 & 3 & 3 & 1 & 5 & 5 & - \\
\hline \multicolumn{8}{|l|}{ Predators } \\
\hline Damsel flies, 6 spp. & 5.3 & 3.6 & 2.2 & 4.1 & 4.0 & 0 & 0 \\
\hline Cyrtorhinus lividipennis & 6.2 & 2.2 & 0.6 & 0.2 & 0.6 & 3 & - \\
\hline Orius tantillus & 0.0 & 7.4 & 1.8 & 0.4 & 0.5 & 3 & - \\
\hline Casnoidea indica & 3.2 & 4.7 & 0.7 & 0.2 & 0.2 & 4 & - \\
\hline Paederus fuscipes & 6.4 & 3.6 & 1.0 & 0.2 & 0.2 & 6 & - \\
\hline
\end{tabular}

* \% fields with leaf damage

** 10 sequential sites only

1= Seedling; $2=$ Basal tillering; $3=$ Elongation; $4=$ Elongation of nodal tillering; $5=$ Flowering , ripening

All seven Acrididae (short-horned grasshoppers and locusts) are rice pests but are nonswarming species, their numbers being fairly consistent throughout the deep water rice season (Table 2). Three Oxya spp. (paddy rice grasshoppers) were the most numerous; Oxya velox which is adapted to deep flooding, lays its eggs between stems and leaf axils 3-5 cm above the water line, while the nymphs are semi-aquatic, their hind legs adapted for swimming. The two Atractomorpha spp. (Pyrgomorphidae) are closely related to the Acrididae. 
Three Tettigonidae (long-horned grasshoppers and katydids) were recorded (Table 2). Among the most abundant was Conocephalus longipennis, a minor pest - which is also a predator - and two non-pest species, Euconocephalus ?incertus and Pusana levis. There were two gryllids (crickets) Modicogryllus ?conformatus and Eucyrtus concinnus, a minor pest. The fossorial mole cricket, Gryllotalpa africana (Gryllotalpidae) a minor pest, was fairly common before flooding but is driven out of the fields with flooding. The numbers of tettigonids and gryllids built up during the flood receding period (Table 3 ).

Table 4. Checklist of fauna classified as predators in deepwater rice, Bangladesh, 1977-80. Compiled from sweepnet catches, hand collection, reared in insectary, light trap catches, pitfall traps and underwater net

\begin{tabular}{|c|c|c|}
\hline Taxon & Scientific name & Family \\
\hline Odonata & $\begin{array}{l}\text { Acisoma panorpoides Rambur } \\
\text { Agriocnemis pygmaea (Rambur) } \\
\text { Agriocnemis lactiola Selys } \\
\text { Brachythemis contaminata (F.) } \\
\text { Ceriagrion coromandelianum (F.) } \\
\text { Enallagma sp. } \\
\text { Ishnura aurora Brauer } \\
\text { Neurothemis tullia (Drury) } \\
\text { Pseudagrion sp. }\end{array}$ & $\begin{array}{l}\text { Libellulidae } \\
\text { Coenagriidae } \\
\text { Coenagriidae } \\
\text { Libellulidae } \\
\text { Coenagriidae } \\
\text { Coenagriidae } \\
\text { Coenagriidae } \\
\text { Libellulidae } \\
\text { Coenagriidae }\end{array}$ \\
\hline Orthoptera & Conocephalus longipennis (de Haan) & Tettigoniidae \\
\hline Dermaptera & Labidura riparia (Pallus) form Bengalensis & Labiduridae \\
\hline Dictyoptera & Unknown & Mantidae \\
\hline $\begin{array}{l}\text { Hemiptera } \\
\text { Heteroptera }\end{array}$ & $\begin{array}{l}\text { Cyrtorhinus lividipennis Reuter } \\
\text { Micronecta altera Wrobl. } \\
\text { Micronecta haliploides Breddin } \\
\text { Micronecta (Synaptonecta) issa (Distant) } \\
\text { Micronecta lubibunda Bredd. } \\
\text { Micronecta punctata (Fieb.) } \\
\text { Micronecta siva (Kirkaldy) } \\
\text { Orius tantillus (Motsch.) } \\
\text { Paramixia singalensis (Dist.) } \\
\text { Plea pelopea Distant } \\
\text { Plea pallescens Distant } \\
\text { Sirthenea flavipes Stål complex } \\
\text { Sphaerodema annulatum (Fabricius) } \\
\text { Sphaerodema molestum Dufour }\end{array}$ & $\begin{array}{l}\text { Miridae } \\
\text { Corixidae } \\
\text { Corixidae } \\
\text { Corixidae } \\
\text { Corixidae } \\
\text { Corixidae } \\
\text { Corixidae } \\
\text { Anthocoridae } \\
\text { Miridae } \\
\text { Pleidae } \\
\text { Pleidae } \\
\text { Reduvidae } \\
\text { Belastomatidae } \\
\text { Belastomatidae }\end{array}$ \\
\hline Diptera & $\begin{array}{l}\text { Anatrichus pygmaeus Lamb. } \\
\text { Carcellia sp. }\end{array}$ & $\begin{array}{l}\text { Chloropidae } \\
\text { Tachinidae }\end{array}$ \\
\hline Coleoptera & $\begin{array}{l}\text { Aeoloderma brachmana Cand. } \\
\text { Apalochrus fasciatus (F.) } \\
\text { Apalochrus nr malabarensis Pic. } \\
\text { Bagous } 2 \text { spp. } \\
\text { Berosus bowringi d'Orchymont * } \\
\text { Berosus pulchellus Macl. * } \\
\text { Bledius lucidus Sharp * } \\
\text { Bledius nr beesoni Cam. * } \\
\text { Brumoides suturalis (F.) } \\
\text { Canthydrus laetabilis (Walker) * } \\
\text { Casnoidea indica (Thunb.) } \\
\text { Chilocorus ?politus Muls. } \\
\text { Chlaenius quadricolor (Ol.) } \\
\text { Chlaenius xanthospilus Wied. } \\
\text { Cicindela minuta Ol. } \\
\text { Cicindela sexpunctata Fabr. } \\
\text { Colliuris fuscipennis (Chd.) } \\
\text { Cybister sp. } \\
\text { Diplocheila polita (F.) }\end{array}$ & $\begin{array}{l}\text { Elateridae } \\
\text { Melyridae } \\
\text { Melyridae } \\
\text { Curculionidae } \\
\text { Hydrophilidae } \\
\text { Hydrophilidae } \\
\text { Staphylinidae } \\
\text { Staphylinidae } \\
\text { Coccinellidae } \\
\text { Dytiscidae } \\
\text { Carabidae } \\
\text { Coccinellidae } \\
\text { Carabidae } \\
\text { Carabidae } \\
\text { Cicindelidae } \\
\text { Cicindelidae } \\
\text { Carabidae } \\
\text { Dytiscidae } \\
\text { Carabidae }\end{array}$ \\
\hline
\end{tabular}




\begin{tabular}{|c|c|c|}
\hline & $\begin{array}{l}\text { Drypta flavipes Wied. } \\
\text { Elaphropus poecilopterus (Bates) } \\
\text { Enorchrus esuriens (Walker) * } \\
\text { Enorchrus flavicans (Reg.) * } \\
\text { Guignotus orientalis (Clark) * } \\
\text { Heteroderes sp. } \\
\text { Helochares sp. * } \\
\text { Hydrophilus ? rufocinctus (Bedel) } \\
\text { Hydrovatus confertus Sharp } \\
\text { Laccobius affinis Knisch * } \\
\text { Laccophilus elegans Sharp * } \\
\text { Lymnastis pilosus Bates } \\
\text { Oosternum horni d'Orchymont * } \\
\text { Paederus fuscipes Curtis } \\
\text { Scymnus nubilus Muls. } \\
\text { Stenus fistulosus Benick } \\
\text { Stenus tricarinatus Kraatz } \\
\text { Verania discolor (F.) }\end{array}$ & $\begin{array}{l}\text { Carabidae } \\
\text { Carabidae } \\
\text { Hydrophilidae } \\
\text { Hydrophilidae } \\
\text { Dytiscidae } \\
\text { Elateridae } \\
\text { Hydrophilidae } \\
\text { Hydrophilidae } \\
\text { Dytiscidae } \\
\text { Hydrophilidae } \\
\text { Dytiscidae } \\
\text { Carabidae } \\
\text { Hydrophilidae } \\
\text { Staphylinidae } \\
\text { Coccinellidae } \\
\text { Staphylinidae } \\
\text { Staphylinidae } \\
\text { Coccinellidae }\end{array}$ \\
\hline Hymenoptera & $\begin{array}{l}\text { Monomorium sp. pharaonis group } \\
\text { Pheidole sp. }\end{array}$ & $\begin{array}{l}\text { Formicidae } \\
\text { Formicidae }\end{array}$ \\
\hline $\begin{array}{l}\text { Arachnida } \\
\text { Araneida }\end{array}$ & $\begin{array}{l}\text { Bionor sp. } \\
\text { Clubiona japonicola Boesenberg et Strand } \\
\text { Clubiona sp. } \\
\text { Lycosa annandalei Gravely } \\
\text { Tetragnatha javana (Thorell) } \\
\text { Tetragnatha vermiformis (Emerton) } \\
\text { Thomisus cheranpunjius Tikader }\end{array}$ & $\begin{array}{l}\text { Salticidae } \\
\text { Clubionidae } \\
\text { Clubionidae } \\
\text { Lycosidae } \\
\text { Tetragnathidae } \\
\text { Tetragnathidae } \\
\text { Thomisidae }\end{array}$ \\
\hline
\end{tabular}

* Light trap at Agrakhola in rabi season only

\section{Homoptera}

The 30 leafhoppers and planthoppers belong to six families of which 18 Jassidae (Cicadellidae, leafhoppers) were dominant (Table 2). There was at least one unidentified species in each of the families Cercopidae, Membracidae, Fulgoridae (occasionally in preand postflood periods) and Aleurodidae (white flies), giving a total of 34 homopteron species collected in deepwater rice. Twelve species are regarded as rice pests: 7 jassids, 2 delphacids, and one each from the Coccidae, Aphididae and Meenoplidae (Table 2). Sweepnetting was particularly effective for jassids. Mixed populations of Nephotettix virescens and $N$. nigropictus (green leafhoppers) were nearly always the most abundant leafhoppers throughout the deepwater rice season, and both are major rice pests. Peak numbers usually occurred in flood receding period (Table 3). Thaia oryzivora, orange leafhopper, a minor pest, was present in small numbers until the end of the flood season, highest numbers occurring on boro rice (Table 3). All other 15 jassids occurred in low or very low numbers throughout the season, and six species occurred only in preflood or flood receding periods. Populations of Empoascanara simillima and Balclutha spp. (grass leafhoppers) were slightly higher in winter, with one minor buildup of Balclutha in flood receding period, and one minor buildup of $H$. porrectus in the preflood period.

Of the delphacids, Sogatella furcifera, whitebacked planthopper, was the most abundant and the only delphacid to occur in significant numbers during the flooding period (Table 3). Populations of Nilaparvata lugens, brown planthopper, a serious potential pest, were low in preflood period and very low in the flooding period. Opiconsiva dodona (Delphacidae) and the strikingly marked Nisia atrovenosa (Menoplidae), present in low numbers before flooding, were not evident during the main flooding period and showed a moderate increase in the flood receding period. The large black Oliarus hodgarti (Cixiidae) was very rare in most catches before flooding. Six aphids occurred in small numbers in deepwater rice 
fields (Table 2), with the highest numbers in the rabi crops. Hysteroneura setariae is a minor pest of rice in Asia and Rhopalosiphum maidis is a grass-feeding species. The other aphids probably feed mainly on other crops. White flies (Aleurodidae) were taken in very small numbers throughout the deepwater rice season. The rice mealy bug, Brevennia rehi (Pseudococcidae), a minor pest, was recorded irregularly, mainly before flooding.

\section{Heteroptera}

The seven phytophagous Heteroptera belong to four families (Table 2), of which the two Alydidae and two Pentatomidae are regarded as rice pests. Leptocorisa acuta and L. oratoria, rice seed bugs, were present in low numbers throughout the season (Table 3). Menida histrio, ear-head shield bug, was the dominant pentatomid in deepwater rice but never built up in large numbers. The rice black bug, Scotinophara coartata, needs moist conditions for development and favours marshy areas. The three other identified Heteroptera in Table 2, and three species named only to family, were rare in deepwater rice.

\section{Thysanoptera}

Thrips species damaged the leaves of young rice plants. The five species from deepwater rice belong to two families, and all are known as rice pests (Table 2). Chloethrips oryzae and Stenchaetothrips biformis were the most commonly associated with rice showing the highest numbers just prior to flooding (Table 3).

\section{Lepidoptera}

The 26 Lepidoptera belong to six families of which 13 were Noctuidae and nine were Pyralidae (Table 2). There was also one unidentified lasiocampid. Sixteen Lepidoptera are regarded as rice pests. A white moth, strongly resembling white stem borer, Scirpophaga innotata (Walker), appeared in very large numbers towards the end of the deepwater rice season and was later named as Scirpophaga virginia Schultze.

Three stem borers were recorded. Scirpophaga incertulas, yellow stem borer (Pyralidae), was usually dominant, especially during the main flooding season from the end of June to mid October when it comprised $95-100 \%$ of all stem borer larvae. Incredibly high numbers of yellow stem borer moths were recorded in the light trap at Agrakhola for broods 3 to 6 from mid July to mid October with up to 50 immatures $/ \mathrm{m}^{2}$ from stem dissections (Catling and Islam, 1995). Chilo polychrysus, dark-headed borer (Pyralidae), and Sesamia inferens, pink borer (Noctuidae), were present mainly before flooding and at flood receding periods.

Cnaphalocrocis medinalis, rice leaffolder (Pyralidae), which consistently fed on deepwater rice throughout the season (Table 3), and Mythimna separata, ear-cutting caterpillar (Noctuidae), are both significant rice pests. Several other lepidopterous leafeaters are minor pests of deep water rice. The larvae of M. separata and Spodoptera mauritia, rice swarming caterpillar (Noctuidae), hide away during the day and pupate either in an earthen cell, in flooded fields at the base of the plant, or along the bunds. The large, distinctive rice skipper, Pelopidas agna, (Hesperiidae), was the most abundant lepidopterous leafeater after leaffolder. The skipper Parnara guttata, known to occur in Bangladesh rice, was not taken in deepwater rice. Nymphula depunctalis, rice caseworm (Pyralidae), is adapted to prolonged flooding: the larvae are semi-aquatic, making rice cases that float on the water and in which they pupate on rice stems. Moderate numbers of Nymphula affinialis were recorded at light during the rabi season. Psalis pennatula, rice hairy caterpillar (Lymantriidae), was present in low numbers on rice and beneath winter stubbles but was never taken in the light trap. The rice green 
semiloopers, Naranga diffusa and N. aenescens (Noctuidae), sometimes occurred in low numbers, while Melanitis lede ismene, rice butterfly (Satyridae), was very rare in deepwater rice. Two closely related leafeaters, Marasmia exigua (Butler) and M. patnalis Bradley, known to occur in Bangladesh with $C$. medinalis, were not identified from deepwater rice.

\section{Three noctuids}

Agrotis ipsilon, Heliothis armigera and Spodoptera cilium, all minor rice pests, were taken in the light trap during the rabi season but were not shown to be associated with deepwater rice. Another four noctuids: Chrysodeixis chalcites, C. eriosoma, Diachrysia orichalcea, and Elydna erigida, were also taken in small numbers at light in the rabi season, but are not regarded as rice pests. The arctiid, Creatonotos gangis, was caught in fair numbers in the light trap.

\section{Diptera}

The bulked Diptera material from the sweepnets included 28 families where the Ephydridae, Chloropidae and Muscidae made up more than three-quarters of the material. Most of the nine dominant families had their highest numbers in the preflood and flood receding periods and were less active $(<10 \%$ of the seasonal totals) during the main flooding period. Very low numbers of Ephydridae, Sarcophagidae, Agromyzidae and Empididae occurred during the flooding period.

Of the 33 Diptera identified to species, 11 were Chloropidae, six Chironomidae, four Tachinidae and three Muscidae. At Agrakhola, Chironomidae represented more than half of the Diptera catches in 1977 with Chloropidae and Ephydridae making up a third of the material.

Eleven dipterous species are classified as phytophages and four of them are recognized as minor pests of deepwater rice (Table 2). Atherigona spp. are seedling maggots, while the Chlorops spp., Oscinella spp. and Pachylophus rufescens, and all the Chloropidae, are definitely phytophagous. All were recorded in small or very small numbers in the sweeps $(1-2 / 100$ single sweeps), mostly before flooding or in the flood receding periods, with low levels of leaf damage and an occasional small population buildup.

\section{Coleoptera}

The 98 species of Coleoptera identified from deepwater rice belong to 18 families. To this are added 11 species identified to family only, and there were still rarer species remaining totally unidentified, about which little is known. Tables 4 and 6 also show that 28 Coleoptera were collected by the light trap during the rabi season from December 1979 to February 1980 - that is not directly from deepwater rice, and none of them are known as rice pests.

Thirty-eight Coleoptera were classified as phytophagous of which seven are regarded as rice pests (Table 2). Two are significant deepwater rice pests. Rice hispa, Dicladispa armigera (Chrysomelidae), completes its life cycle within a leaf tunnel and the insect has high moisture requirements. Numbers built up in the preflood period when five outbreaks were recorded, but declined abruptly with deep flooding (Table 3). The minute flea beetle, Chaetocnema basalis (Chrysomelidae), was the most common coleopterous leafeater before flooding (>500 beetles/100 single sweeps and 17 outbreaks) but declined to low numbers during the flood season (Table 3). This was also the first record of flea beetle on rice in Bangladesh and no developmental stages were observed. Tanymecus indicus also definitely feeds on deepwater rice. 
Most curculionid larvae are herbivorous. Myllocerus blandus is known in Bangladesh paddy rice and the univoltine root weevil Hydronomidius molitor attacks rice roots in India. Bagous spp. are associated with aquatic plants and the adults are aquatic, while some Nanophyes spp. feed on flowers and crop seeds. The non-pest Curculionidae and the closely-related Apionidae are mostly phytophagous developing in roots, stems, flowers, fruits and seeds. Taken together this group occurred in low numbers at 0.4-2/100 single sweeps in preflood, and $<1 / 100$ single sweeps for the rest of the season (Table 3 ). Both families were more abundant in the rabi season.

The adults and larvae of the Chrysomelidae are mainly herbivorous. Monolepta signata, the white spotted flea beetle of India, occurred in very low numbers (2-3 beetles/100 single sweeps in 1978) and activity was negligible during flooding. Altica caerulea and several other Altica spp. present widely in South-East Asia, are leafeaters; they are jumping beetles with thickened femora. The two Formicomus spp. (Anthicidae) are probably phytophages since two others belonging to this genus are minor pests of rice and cereals. Bruchidae mostly live in seeds, especially legumes.

The two Phalacridae beetles are probably phytophagous. Stilbus curvolineatus, recorded in nearly a half of the fields, was more abundant in preflood with five population buildups; declined in the flood period and increased again (4-5/100 single sweeps) in flood receding period (Table 3). It was usually seen together with flea beetle but in smaller numbers. The remaining group of diverse beetles was present in low numbers before flooding, declined to even lower numbers for the rest of the deep water rice season, and showed variable numbers in the rabi season.

\section{Nematoda}

The stem nematode causing ufra disease, white tip nematode and root-knot nematode were evident in deepwater rice fields (Table 2). Tylenchorhynchus martini and root nematode were also identified from deepwater rice in the 1970s (Cox, 1980).

\section{Crustacea}

The freshwater crab Sartoriana spinigera feeds on young deepwater rice plants in the early flooding period (Table 2). Also identified by other workers were Macrobrachium lamarrei, a prawn, and Paratelphusa hydromus.

\section{Mollusca}

Only one of the molluscs collected in deepwater rice is clearly phytophagous: Pila pesmei eats the soft elongating rice stems (Islam, 1989).

\section{Predators}

The guild of predators consisted of 75 species: eight insect orders and the Arachnida (Table $4)$.

\section{Odonata}

Six damselflies (Coenagriidae) occurred in deepwater rice (Table 4). Their numbers are increasing as the plant canopy enlarged. Effective predators of moths, nymphs and adult leaf- and planthoppers, gall midges and chironomid midges were taken throughout the season at mean numbers varying from 2-5/100 single sweeps (Table 3), and were less abundant in the rabi season. Seasonal population fluctuations were similar in both the years and there were no population buildups. These numbers may have been an underestimate 
since damselflies tend to fly in the lower plant canopy. The three dragonflies (Libellulidae) occurred at means of $<1 / 100$ single sweeps during preflood and increased to $2-4 / 100$ single sweeps towards the end of flooding period but were less important predators (and they also attack damselflies).

\section{Orthoptera, Dermaptera And Dictyoptera}

Conocephalus longipennis (Tettigoniidae), an effective predator of lepidopterous eggs, especially YSB egg masses, also attacks the larvae and pupae of leafeaters. It was most active in September and October when stem borer egg masses are abundant.

Earwigs (Dermaptera) are omnivorous and predacious. A single species, Labidura riparia, was active in April and May in the pitfall traps where it was probably feeding on lepidopterous insects. It was rarely seen in the flooding period. An unidentified mantid (Dictyoptera) was occasionally recorded in the sweeps.

\section{Heteroptera}

The 14 predacious Heteroptera belonged to six families (Table 4). The most abundant, Cyrtorhinus lividipennis (Miridae), an important predator of brown planthopper, whitebacked planthopper and green leafhoppers, occurred in preflood period at 2-6/100 sweeps, with three population buildups before flooding in 1977, declined to less than $1 / 100$ single sweeps for the whole flooding season (Table 3), and was not taken in the rabi season. A black mirid, Paramixia singalensis, also occurred in low numbers during preflood. Orius tantillus (Anthocoridae), a generalist predator of Lepidoptera, hoppers and thrips, was present in similar numbers to C. lividipennis but was more irregular (Table 3 ) and was rare in the rabi season.

Water boatmen (Corixidae), the dominant family of aquatic Hemiptera, generally live in the benthos and feed on diatoms, algal cells and organic ooze. However, six minute Micronecta spp. were identified (Table 4) which feed on insect larvae, including mosquitos. Identified items also include (Table 4) two small, predatory Pleidae (pygmy backswimmers), and two Belastomatidae (giant water bugs) feeding on insects, crustaceans, small fish and amphibians. Sirthenia flavipes (Reduviidae) probably also preys on rice insects. One unidentified form of predacious Nabidae occurred occasionally in the preflood period.

\section{Thysanoptera}

An unidentified red-banded thrips, regularly observed in low to moderate numbers in deepwater rice, is probably predacious.

\section{Diptera}

Only two predacious Diptera were identified to species level. Anatrichus pygmaeus (Chloropidae), the most abundant, which attacks stem borer larvae and mealy bug, occurred in small numbers during preflood, and was most numerous in the flood receding period. Carcellia sp. (Tachinidae) attacks dark-headed borer and mealy bug.

\section{Coleoptera}

The 38 predacious Coleoptera belonged to nine families (Table 4). Eight Carabidae (ground beetles), which attack lepidopterous larvae and pupae, earthworms and snails, were identified. Casnoidea indica, a striking black and brown-banded beetle was very common. Present at 3-5/100 single sweeps including four population buildups in preflood period, numbers declined to $<1 / 100$ single sweeps with flooding (Table 3). Another seven 
Carabidae occurred, mainly in the pitfall traps from February to May 1978, where the most abundant were: Chlaenius xanthospilus, C. quadricolor and Diplocheila polita.

Some forms of Staphylinidae (rove beetles) prey on insects; many are predacious with aggressive larvae (and a few are true parasites). The most abundant coleopterous predator in deepwater rice, Paederus fuscipes, attacks leaf- and planthoppers, and the eggs and larvae of lepidopterous borers and leafeaters. Greatest activity occurred before flooding with five population buildups, and numbers declined sharply during the flooding period (Table 3). Numbers may have been under-estimated since they hide away near the water surface during the hot part of the day. Stenus spp. attack Collembola while the Bledius spp. are also probably predacious.

Coccinellid adults and larvae are typically non-specific predators of Homoptera, Lepidoptera, thrips and mites, but they also feed on pollen. Besides the four identified species there were several unidentified forms (Table 4). The most abundant was Chilocorus politus which in 1978 occurred at 3.6 beetles/100 single sweeps prior to flooding with one population buildup. It declined during the main flooding period $(<1 / 100$ single sweeps), but then built up to significant numbers in the flood receding period (6.5/100 single sweeps, three population buildups) when the beetles were feeding on rice pollen. Verania discolor was less numerous with the highest activity in late preflood period (5/100 sweeps), low numbers during flooding and no significant buildup in the flood receding period (1.6/100 single sweeps). The other coccinellids, Brumoides suturalis and the minute Scymnus nubilus, nearly always occurred at $<1$ beetle/100 single sweeps.

Of the two Cicindelidae (tiger beetles), Cicindela minuta was present in small numbers in sweeps in preflood and late flood receding periods. C. sexpunctata was rare. Aeoloderma brachmana was the most common of the Elateridae. Heteroderes sp. is a predator of pink borer. There were also two unidentified elaterids that occurred at means of 1/100 single sweeps in preflood period and $<1 / 100$ single sweeps for the rest of the deepwater rice season. Melyridae larvae are mostly predacious while the adults are mainly pollen feeders.

Two families of aquatic beetles were well represented. The six Dytiscidae (true water beetles) identified (Table 4) are diving beetles that are almost entirely predacious on immature insects but also attack snails, earthworms and small frogs. The eight Hydrophilidae are aquatic or live in moist soil on decomposing vegetable matter but most larvae are predacious on insect larvae, earthworms and small frogs.

\section{Hymenoptera}

The two ants (Formicidae), active in deepwater rice: Monomorium sp. and Pheidole sp. (Table 4), are probably predacious since closely related forms prey on rice stem borers. Ants were particularly active before flooding and sometimes appeared in sweeps at flood inundation when they were marooned on isolated plants above the water level. On the other hand, ants also attended honeydew-secreting Homoptera such as mealy bugs where they encourage pest outbreaks. An unidentified true wasp (Vespidae) occurring in sweeps probably attacks exposed lepidopterous larvae. The red fire ant, Solenopsis geminata (Fab.), is also present in rice ecosystems in Bangladesh.

\section{Arachnida}

The sweeps consistently caught large numbers of a variety of spiders attacking virtually all stages of lepidopterous borers and leafeaters, as well as leafhoppers and planthoppers. 
Seven species belonging to five families were identified (Table 4). Two tetragnathids, which are nocturnal web spinners, were most abundant towards the end of the flooding period. Lycosids, wolf spiders, prey on nymphs and adults of whitebacked planthopper and green leafhoppers, and several are aquatic, diving below the water carrying an air bubble. Lycosa annandalei, particularly abundant in the first half of the season where it was sometimes dominant, is an important predator of planthoppers. Two Clubiona species, which make distinctive tents or sacs for hatching their young, were present in low to moderate numbers of up to 10/100 single sweeps throughout the deepwater rice season. Thomisus cheranpunjius (Thomisidae) and Bionor sp. (Salticidae) were less numerous, seldom exceeding 1-2 spiders/100 single sweeps.

The bionomics of the spider complex was studied by direct field observation and by sweepnetting. Immature forms made up a large proportion of many catches. Spider numbers were remarkably similar over the three floodplains and over both years at the ten sequential sites.

In 1977, mean densities rose from 18 spiders/100 single sweeps in the preflood period to $62 / 100$ single sweeps at flood receding, this pattern being repeated in 1978 at a slightly higher amplitude (Figure 2). A similar pattern of abundance in sweeps, and also in numbers of spider egg sacs, was recorded in 1977 and 1978 at Agrakhola (Catling and Islam 1995). Spider activity continued at high levels in the rabi season from December to February (18$58 / 100$ single sweeps), the tetragnathids dominating. Very large spider numbers were sometimes encountered during the main flooding period: over 100 spiders per sweep sample was common, and catches of $>400 / 100$ single sweeps were recorded once in 1977 and three times in 1978 (Figure 2).

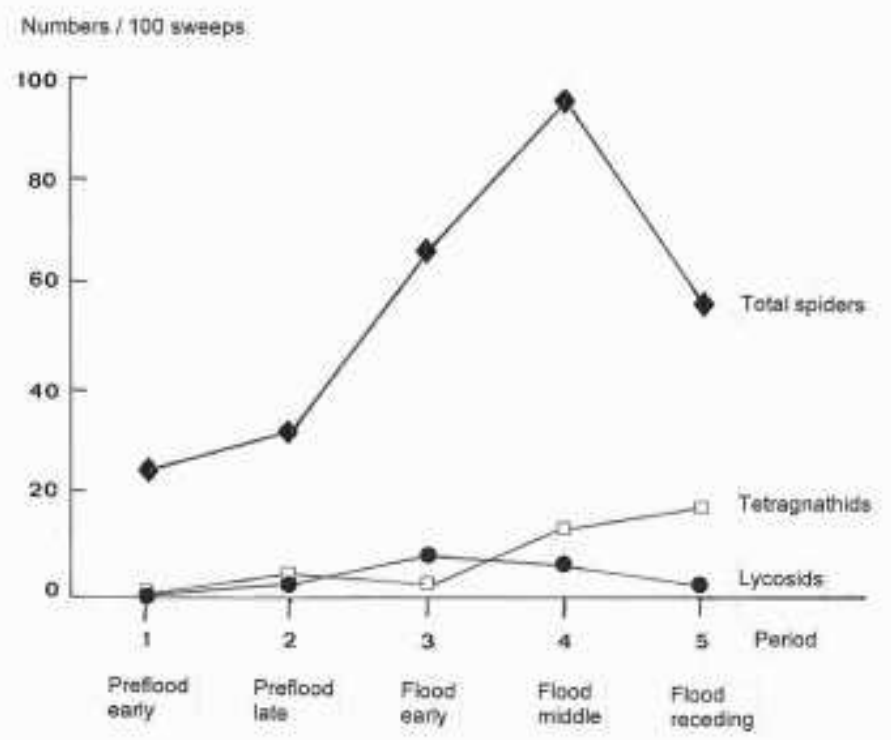

Fig. 2. Population fluctuations of spiders from surveys in deepwater rice, Bangladesh, 1978. Total spiders include all species and all stages; tetragnathids and lycosids are shown as numbers of adults and near adults only

Densities of tetragnathids and lycosids were similar up to mid flooding, after which lycosids declined while tetragnathids went on to reach their highest densities at the end of the season. However, since tetragnathids are mid canopy predators, which may be more 
effectively caught in sweepnets, differences in abundance between the two main spider groups, and the decline in total spiders in period 5, may be due to sampling error in the prostrate deepwater rice canopy present at the end of the season.

In the 1977 and 1978 sweeps, the ratio of spiders to leafhoppers plus planthoppers was widest before flooding when spider populations were building (mean 1:10, range 6.6 to 14.3). This ratio narrowed appreciably during the flooding period (mean of around 1:2, range 0.4 to 2.9 ), again indicating the important role played by spiders.

\section{Parasitoids}

The guild of parasitoids consisted of one nematode, eight Diptera, 65 Hymenoptera and one strepsipteran (Table 5). Most of the identified material was reared from parasitized hosts collected in the field, the balance came from the sweepnets.

Table 5. Checklist of fauna classified as parasitoids in deepwater rice, Bangladesh, 1977-1980. Compiled from sweepnet catches, hand collection or reared in insectary.

\begin{tabular}{|c|c|c|}
\hline Taxon & Scientific name & Family \\
\hline Nematoda & Unknown & Mermithidae \\
\hline $\begin{array}{l}\text { Insecta } \\
\text { Diptera }\end{array}$ & $\begin{array}{l}\text { Blepharella lateralis Macquart } \\
\text { Pipunculus sp. } \\
\text { Pseudogonia rufifrons Wied. } \\
\text { Sarcophaga spp. } \\
\text { Sepedon ferruginosa Wied. } \\
\text { Sepedon sphegea Fabr. } \\
\text { Sturmiopsis inferens Tns. } \\
\text { Tomosvaryella sp. }\end{array}$ & $\begin{array}{l}\text { Tachinidae } \\
\text { Pipunculidae } \\
\text { Tachinidae } \\
\text { Sarcophagidae } \\
\text { Sciomyzidae } \\
\text { Sciomyzidae } \\
\text { Tachinidae } \\
\text { Pipunculidae }\end{array}$ \\
\hline Hymenoptera & $\begin{array}{l}\text { Agathis sp. } \\
\text { Amauromorpha sp. } \\
\text { Anagrus sp. } \\
\text { Apanteles argiope Nixon } \\
\text { Apanteles cypris Nixon } \\
\text { Apanteles (=Cotesia) flavipes Cam. } \\
\text { Apanteles ruficrus Haliday } \\
\text { Apanteles schoenobii Wilkinson } \\
\text { Brachymeria albotibialis (Ashmead) } \\
\text { Brachymeria megaspila (Cameron) } \\
\text { Brachymeria podagrica (F.) } \\
\text { Brachymeria secundaria (Rus.) } \\
\text { Brachymeria sp. } \\
\text { Bracon chinensis Szep. } \\
\text { Bracon hispae (Vier.) } \\
\text { Ceraphron nr figiensis } \\
\text { Ceraphron sp. } \\
\text { Charops sp. } \\
\text { Cheiloneurus sp. } \\
\text { Chelonus nr munakatae (Munakata) } \\
\text { Chrysonotomyia ?thakerei Subba Rao } \\
\text { Elasmus ?claripennis Cameron } \\
\text { Elasmus sp. } \\
\text { Eucoilidea sp. Ash. } \\
\text { Eupelmus sp } \\
\text { Euplectus sp. } \\
\text { Eupteromalus parnarae Gahan } \\
\text { Eurytoma sp. } \\
\text { Exoryzae schoenobii (Williams) } \\
\text { Gonatocerus sp. } \\
\text { Goniozus sp. } \\
\text { Gotra sp. } \\
\text { Haplogonatopus oricutalis (Roh.) }\end{array}$ & $\begin{array}{l}\text { Braconidae } \\
\text { Ichneumonidae } \\
\text { Mymaridae } \\
\text { Braconidae } \\
\text { Braconidae } \\
\text { Braconidae } \\
\text { Braconidae } \\
\text { Braconidae } \\
\text { Chalcididae } \\
\text { Chalcididae } \\
\text { Chalcididae } \\
\text { Chalcididae } \\
\text { Chalcididae } \\
\text { Braconidae } \\
\text { Braconidae } \\
\text { Ceraphronidae } \\
\text { Ceraphronidae } \\
\text { Ichneumonidae } \\
\text { Encyrtidae } \\
\text { Braconidae } \\
\text { Eulophidae } \\
\text { Elasmidae } \\
\text { Elasmidae } \\
\text { Eulophidae } \\
\text { Eupelmidae } \\
\text { Eulophidae } \\
\text { Pteromalidae } \\
\text { Eurytomidae } \\
\text { Braconidae } \\
\text { Mymaridae } \\
\text { Bethylidae } \\
\text { Ichneumonidae } \\
\text { Dryinidae }\end{array}$ \\
\hline
\end{tabular}




\begin{tabular}{|c|c|c|}
\hline & $\begin{array}{l}\text { Hemiptarsenus semialbiclava (Girault) } \\
\text { Hemiteles sp. } \\
\text { Hormius sp. } \\
\text { Idris } 3 \text { spp. } \\
\text { Isotima javensis (Rohwer) } \\
\text { Isotima sp. } \\
\text { Microplitis sp. } \\
\text { Orgilus sp. } \\
\text { Oronotus sp. } \\
\text { Platygaster oryzae Cameron } \\
\text { Platygaster sp. } \\
\text { Pteromalus sp. } \\
\text { Rhabdepyris sp. } \\
\text { Rhaconotus sp. } \\
\text { Rhopus sp. } \\
\text { Shirakia schoenobii Viereck } \\
\text { Stenobracon nicevillei (Bingham) } \\
\text { Telenomus dignoides Nixon } \\
\text { Telenomus dignus (Gahan) } \\
\text { Telenomus rowani Gahan } \\
\text { Temelucha stangli (Ashmead) } \\
\text { Temelucha philippinensis (Ashmead) } \\
\text { Tetrastichus ayyari Rohwer } \\
\text { Tetrastichus schoenobii Ferriere } \\
\text { Trichogramma japonicum Ashmead } \\
\text { Trichogramma pallidiventris Nagaraja } \\
\text { Trichopria sp. } \\
\text { Tropobracon sp. } \\
\text { Xanthopimpla flavolineata Cameron } \\
\text { Xephomastix poonensis (Mani \& Kaul) }\end{array}$ & $\begin{array}{l}\text { Eulophidae } \\
\text { Ichneumonidae } \\
\text { Braconidae } \\
\text { Scelionidae } \\
\text { Ichneumonidae } \\
\text { Ichneumonidae } \\
\text { Braconidae } \\
\text { Braconidae } \\
\text { Ichneumonidae } \\
\text { Platygasteridae } \\
\text { Platygasteridae } \\
\text { Pteromlidae } \\
\text { Bethylidae } \\
\text { Braconidae } \\
\text { Encyrtidae } \\
\text { Braconidae } \\
\text { Braconidae } \\
\text { Scelionidae } \\
\text { Scelionidae } \\
\text { Scelionidae } \\
\text { Ichneumonidae } \\
\text { Ichneumonidae } \\
\text { Eulophidae } \\
\text { Eulophidae } \\
\text { Trichogrammatidae } \\
\text { Trichogrammatidae } \\
\text { Diapriidae } \\
\text { Braconidae } \\
\text { Ichneumonidae } \\
\text { Encyrtidae } \\
\end{array}$ \\
\hline Strepsiptera & ? Halictophagus sp. & Halictophagidae \\
\hline
\end{tabular}

\section{Nematoda}

An unidentified mermithid nematode was observed attacking yellow stem borer larva from July to September each year, sometimes at fairly high rates, with 1-4 nemas emerging from each host. The mermithid was widely distributed in Bangladesh.

\section{Diptera}

The eight Diptera identified as parasitoids belong to four families (Table 5). Although the Tachinidae are an important parasitic family, especially of lepidopterous larvae and adult Coleoptera and Hemiptera, surprisingly few tachinids were recorded in the sweepnet material and in reared hosts. Sturmiopsis inferens was reared from a few dark-headed borer, while Blepharella lateralis and Pseudogonia rufifrons were reared from ear-cutting caterpillar. Sarcophaga sp. (Sarcophagidae) was taken from dark-headed borer and ear-cutting caterpillar. The pipunculids Tomasvaryella sp. and Pipunculus sp. are larval parasitoids of leafhoppers, and one unidentified phorid was reared from ear-cutting caterpillar; both families were present in small numbers in the sweeps. Several sciomyzid larvae attack snails; Sepedon ferruginosa occurring in the flood receding period is an alternate host for Telenomus spp.

\section{Hymenoptera}

The 65 Hymenoptera belong to 17 families (Table 5). To these are added 12 more Hymenoptera identified to family or superfamily only. The 1978 sweepnet material was divided into the two principal hymenopterous superfamilies attacking rice pests. (i) Chalcidoidea - comprising Chalcididae, Trichogrammatidae, Eulophidae, Elasmidae, Scelionidae and several other families, which are mostly small parasitoids. 
(ii) Ichneumonoidea - comprising the larger parasitoids including the Ichneumonidae and Braconidae. The Chalcidoidea (37 species identified) persisted at fairly high levels (1020/100 single sweeps) throughout the deepwater rice season with population buildups of $>60 / 100$ single sweeps once during the preflood period, three times in the main flood period, and once in the flood receding period. By contrast, the Ichneumonoidea (27 species identified) declined in numbers with flood inundation in June and then slowly increased in numbers towards the end of the flooding period; there were two population buildups (>30/100 single sweeps) in preflood and two buildups in the flood receding period.

Braconidae attack the larvae and pupae of borers and leafeaters, while a few are egg/larval parasitoids. Nearly 20 braconid species were collected in the sweeps, and 10 were involved in the parasitic complex of yellow stem borer. Shirakia schoenobii, one of the most abundant species, was a major parasitoid of yellow stem borer in deepwater rice; together with Apanteles sp. These two parasitoids declined with flood inundation, but showed a rapid increase in flood receding period. Fairly high numbers of $S$. schoenobii persisted in the rabi season. Apanteles spp., taxonomically a difficult group, were fairly abundant, being recorded from yellow stem borer, dark-headed borer, pink borer and rice leaffolder. Apanteles flavipes was fairly common and attacked all three rice stem borers, A. schoenobii attacks yellow stem borer, while A. ruficrus was particularly common in rabi season. Chelonus nr. munakata, another important species for yellow stem borer, was rare before flooding but increased during the flooding period. Bracon hispae probably reduces hispa populations in deepwater rice.

The Ichneumonidae parasitize the larvae and pupae of rice borers and lepidopterous leafeaters. At least 10 species were collected in sweeps, and seven species are part of the yellow stem borer complex. Isotima javensis and Temelucha stangli were rare before flooding but increased during flood periods 3-5. Ichneumonids were also reared from ear-cutting caterpillar, rice leaffolder, rice skipper, rice butterfly and hairy caterpillar. Hemiteles sp, caught in the sweeps, is a hyperparasite of Apanteles spp.

Six Scelionidae were identified. Telenomus rowani, which disperses by phoresy, was a major parasite of yellow stem borer eggs at all times, while Telenomus dignus and T. dignoides also attack yellow stem borer eggs. Three Idris spp., common in the sweeps, may parasitize spider eggs, and one Idris sp. reared twice from yellow stem borer may have been a new record.

Dryinidae are endoparasites of jassids, delphacids and fulgorids, the predacious habit of the adult having a greater impact on the host. Small numbers of parasitized whitebacked planthopper adults, and more rarely nymphs, were recorded fairly widely in the sweepnet material in both the years. Parasitized individuals were recognized by the parasite's larval sac emerging from the intersegmental membrane of the host's abdomen. The highest incidence occurred in April and May 1978 when 75\% of whitebacked planthoppers were parasitized (16 sweepnet samples). Parasitism was evident again from October to December but was always low in the main flooding period. A single brown planthopper was parasitized. Dryinid adults caught in the sweeps were identified as Haplogonatopus oricutalis.

Of the six Eulophidae (Table 5), four species attacked deepwater rice pests. Tetrastichus schoenobii, specific to yellow stem borer eggs, is effective at high and low host densities and the larva is predacious. Tetrastichus ayyari attacks yellow and dark-headed stem borer eggs. Chrysotomyia thakeri and Hemiptarsenus semialbiclava were reared from leaf miner. 
Table 5 lists another seven closely related families of the Chalcidoidea accounted for 16 parasitoids. The Chalcididae are parasites of stem borers and lepidopterous leafeaters: five Brachymeria spp. were recorded in sweeps in small numbers, and a Brachymeria species was reared from leaffolder in deepwater rice. Of the Pteromalidae, which are egg/pupal parasites of stem borers and lepidopterous leafeaters, Eupteromalus parnarae, a striking, green iridescent species, was common throughout the season and was reared from yellow stem borer egg masses (where it may be a hyperparasitoid), and from leaf miner and several other leafeaters. Eurytoma sp. (Eurytomidae) caught in the sweeps, attacked yellow stem borer. This genus also contains forms that are hyperparasites of spider eggs. Three encyrtid species were reared from mealy bug, of which Rhopus sp. was sometimes dominant. Trichogramma japonicum and $T$. pallidiventris (Trichogrammatidae) attack yellow stem borer eggs in deepwater rice. Elasmus spp. (Elasmidae) parasitize the larvae of lepidopterous leafeaters, and disperse by phoresy; Elasmus ?claripennis, common during the deepwater rice season, parasitizes yellow and other stem borer larvae. Relatively large numbers of delicate mymarid wasps were collected in sweeps. Two species were identified (Table 5), which attack the eggs of leafhoppers and planthoppers and help to regulate their numbers. They also parasitize gall midge. The Bethylidae are larval parasites of lepidopterous borers and leafeaters. Two species were identified of which Goniozus sp., the most abundant, parasitizes yellow stem borer and leaffolders. Lastly, two Ceraphron spp. caught in the sweeps are probably hyperparasites of Ichneumonidae.

\section{Strepsiptera}

The highly specialized Strepsiptera, placed in a separate order, are parasitoids of jassids and fulgorids; the parasitized, castrated hosts are said to be 'stylopized'. Low numbers of stylopized white leafhopper adults occurred irregularly from May to June and in November, while stylopized Thaia oryzivora and Kolla mimica were more rare. The main parasitic species was tentatively identified as Halictophagus sp.

\section{Scavengers}

The guild of scavengers are predominantly detritivores, decomposers and plankton feeders, including those forms feeding on algae. This important group, which decomposes organic matter, recycles nutrients and thus promotes soil fertility, was more difficult to classify and was under-sampled in the study. Scavengers identified from deepwater rice fields consist of 38 Insecta, predominantly Diptera and Coleoptera, two Acarina and four Mollusca (Table 6).

Table 6. Checklist of fauna classified as scavengers, detritivores and plankton feeders in deepwater rice, Bangladesh, 1977-80. Compiled from sweepnet catches, hand collection, reared in insectary, light trap catches, pitfall traps and underwater net.

\begin{tabular}{|l|l|l|}
\hline Taxon & Scientific name & Family \\
\hline Insecta & & \\
Collembola & Entomobryid sp. & Entomobryidae \\
\hline Ephemeroptera & Unknown & Caenidae \\
\hline Psocoptera & Unknown & Unknown \\
\hline Trichoptera & Dipseudopsis sp. & Polycentropodidae \\
\hline Diptera & Aphanotrigonum $n$ r. fasciellum (Zett.) & Chloropidae \\
& Chironomus sp. & Chironomidae \\
& Cladytanytarsus sp. & Chironomidae \\
& Elliponeura sp. $n$. & Chloropidae \\
& Fiebrigella sp. & Chironomidae \\
& Harnischia curtilamellata Malloch & Chironomidae \\
& Meijerella inaequalis (Becker) & Chloropidae \\
\hline
\end{tabular}




\begin{tabular}{|c|c|c|}
\hline & $\begin{array}{l}\text { Parachironomus sp. } \\
\text { Polypedilum sp. } \\
\text { Scoliophthalmus micans Lamb } \\
\text { Steleocerellus ensifer (Thomson). } \\
\text { Trachysiphonella pallid sp. }\end{array}$ & $\begin{array}{l}\text { Chironomidae } \\
\text { Chironomidae } \\
\text { Chloropidae } \\
\text { Chloropidae } \\
\text { Chloropidae }\end{array}$ \\
\hline Coleoptera & $\begin{array}{l}\text { Anthicus hirsutus Laf. } \\
\text { Anthicus siamensis Pic. } \\
\text { Anthicus suturallis Laf. } \\
\text { Carpelimus indicus (Kraatz) * } \\
\text { Carpelimus siamensis (Fauvel) * } \\
\text { Endomia lunulata Krek. } \\
\text { Heterocerus micans Mam. * } \\
\text { Heterocerus } 5 \text { spp. * } \\
\text { Limnichus micraspis Champ. * } \\
\text { Limnichus obliteratus Champ. * } \\
\text { Melanophthalma prominens Johns. } \\
\text { Onthophagus cervus (F.) * } \\
\text { Onthophagus sternalis Arrow * } \\
\text { Onthophagus triceratops Arrow * } \\
\text { Onthophagus ?falsus Gillet * } \\
\text { Pelochares gibbipennis Champ. * } \\
\text { Pelochares rugiventris Champ. * } \\
\text { ?Prodrasterius sp. }\end{array}$ & $\begin{array}{l}\text { Anthicidae } \\
\text { Anthicidae } \\
\text { Anthicidae } \\
\text { Staphylinidae } \\
\text { Staphylinidae } \\
\text { Anthicidae } \\
\text { Heteroceridae } \\
\text { Heteroceridae } \\
\text { Limnichidae } \\
\text { Limnichidae } \\
\text { Lathridiidae } \\
\text { Scarabaeidae } \\
\text { Scarabaeidae } \\
\text { Scarabaeidae } \\
\text { Scarabaeidae } \\
\text { Limnichidae } \\
\text { Limnichidae } \\
\text { Elateridae }\end{array}$ \\
\hline $\begin{array}{l}\text { Arachnida } \\
\text { Acarina }\end{array}$ & $\begin{array}{l}\text { Ololaelaps sp. } \\
\text { Scheloribates sp. }\end{array}$ & $\begin{array}{l}\text { Laelapidae } \\
\text { Scheloribatidae }\end{array}$ \\
\hline Mollusca & $\begin{array}{l}\text { Indoplanorbis exustus (Deshayes) } \\
\text { Lymnaea auricularia (L.) } \\
\text { Pila pesmei (Morlet) } \\
\text { Vivipara bengalensis (L.) }\end{array}$ & $\begin{array}{l}\text { Planorbidae } \\
\text { Lymnaeidae } \\
\text { Pilidae } \\
\text { Viviparidae }\end{array}$ \\
\hline
\end{tabular}

- Light trap at Agrakhola in rabi season only

\section{Collembola}

The larvae of springtails feed on plankton, detritus and algae; many species are mycetophores feeding on blast spores and hyphae, and sheath blight mycelia. There were occasional records of ?Entomobryid spp. in pre- and postflooded deepwater rice (Table 6). Although grossly under-sampled, field observations indicated that Collembola are an important prey for spiders in flooded fields. Large numbers of an Entomobryid (representing $66 \%$ of all arthropods) were collected by suction in a subsequent study of deepwater rice in Thailand (Catling, 1982, unpublished). Such buildups may be related to the larger amounts of floating detritus, organic matter and algae in the deep water rice neuston on which entomobryids feed.

\section{Ephemeroptera And Psocoptera}

Small numbers of unidentified mayflies (Ephemeroptera) were taken in the light trap during the flooding season. Deepwater rice is probably not a favourable environment because mayfly nymphs have high oxygen requirements. An unidentified psocopteran (booklice) was taken occasionally in the pre- and postflood periods.

\section{Trichoptera}

Closely related to Lepidoptera, the Trichoptera (caddis flies) spend their early stages in freshwater and their presence indicates clean water. Trichoptera are probably an important component of the flooded deepwater rice ecosystem as consumers of diatoms and detritus, but may also feed on crustaceans, annelids and insect larvae. At Agrakhola, the mucilagecovered egg masses of caddis flies were observed on submerged rice and grass stems; adults started to appear in the light trap shortly after flood inundation, their numbers increasing 
steadily to reach a peak of $>1000$ adults/week from early September to mid October. The dominant species was Dipseudopsis sp. whose larvae commonly frequent slow-flowing waters. The larvae make non-portable silken nets (not cases) and crawl on the benthos. Larvae have anal blood-gills and are mainly algal grazers although some are carnivorous.

\section{Diptera}

Saprophytic dipteran families living essentially on organic matter include: Dolichopodidae, Empididae, Scatopsidae and at least 12 others. The larvae of Stratiomyidae and Ceratopogonidae (biting midges) and several others dipteran families, graze on algae. The 12 scavengers identified in deepwater rice belong to the Chironomidae and Chloropidae (Table 6).

The Chironomidae are a largely aquatic family that were probably underestimated during the flood period. Feeding on detritus and algae, the larvae browse in the benthos and live in tubes in the sediment. The short-lived adults are the preferred food of spiders and they tend to stabilize spider populations. Table 6 lists the six Chironomidae those are presumably scavengers (Nartshuk and Yang, 2011) and the highest numbers occurred in early and mid flooding period. They were present in large numbers at Agrakhola and two other fields from June to August but were absent in the dry winter months. The most abundant chironomids: Chironomus sp., Cladytanytarsus sp., Harnischia curtilamellata, Parachironomus sp., Polypedilum sp., as well as most Chloropidae larvae, feed on algae and detritus and are probably an important element in the rice field ecosystem (Harris, K. M., CIE; personal communication, 1980). (Phytophagous forms within the Chloropidae are very difficult to disentangle from the scavengers.)

Ephydridae were taken in large numbers in the sweeps (see earlier) but none were identified to species level. Ephydrids inhabit marshes, attack the stems of aquatic plants, and are detritvores in rice fields; only a few are parasitic.

\section{Coleoptera}

Many coleopterous forms are scavengers or feed on algae or humus in the soil, while others are aquatic. The 22 Coleoptera classified as scavengers belong to seven families (Table 6). More than half of these forms were collected at light in the dry season.

The Anthicidae are omnivorous, though Anthicus spp. and Endomia lunulata are definitely scavengers. Although most Staphylinidae are predators of insects and other invertebrates, some feed on decaying plant material, spores and algae: the two Carpelinus species probably live near water and are scavengers. The Heteroceridae and Limnichidae are small, aquatic beetles living on decaying plant material and algae, while the Lathridiidae, small nonaquatic beetles, live on decaying plant material, moulds and fungi. Most Elateridae larvae (wireworms) are saprophytes. The four Onthophagus spp. (Scarabaeidae) are tropical coprophagous dung beetles and were probably vagrants in deepwater rice.

\section{Arachnida}

Two aquatic oribatid mites: Ololaelaps sp. and Scheloribates sp. (Table 6) probably feed on fungi and green plant material during the flooding period.

\section{Mollusca}

Most molluscs grazing on the periphyton and browsing on the benthos and are termed 'ecosystem engineers'. The dominant molluscs from deepwater rice belong to four different families (Table 6). Three species did not appear to seriously damage rice and are probably 
more important as grazers of algae. The exception, mentioned earlier, is Pila pesmei which also feeds on vascular plants. Cercaria from Indoplanorbis exustus are common in flooded deepwater rice and cause itchy skin in humans.

\section{Microbial disease}

The incidence of microbial infection in the arthropod fauna was overlooked since the entomology team had little experience in this area. However, microbial disease was occasionally observed to affect some insects in the surveys. Firstly, nymphal populations of tettigonids, predominantly Conocephalus longipennis, were heavily attacked each year by an unidentified entomophagous fungus. In October and November, up to a half of nymphs in the sweeps from five widely spaced localities showed an abnormally dark gut colour. Secondly, yellow stem borer cadavers with milky white contents indicating viral infection, and black and rotten larvae, were recorded in the dissections at Agrakhola and Bastia, especially towards the end of the deepwater rice season when larval populations were at their highest (Catling and Islam, 1995).

\section{DISCUSSION AND CONCLUSIONS}

The deepwater rice areas of Bangladesh are close to the original home of Oryza sativa. This traditional crop is part of an ancient agroecosystem and nearly always adjoins large areas of other rice cultural types. In the 1970s, many fields were mixed sown with aus and deepwater rice varieties, while jute was planted in shallow situations. As had been the case for hundreds of years, a virtual monocrop of traditional cultivars was found every year from May to November over large areas of continuously flooded lowland, and in the rabi (dry) season pulses and oil seed crops were grown. Since these studies were carried out, however, the area planted to deepwater rice has declined sharply.

Agricultural chemicals tend to suppress species richness by disorienting the tropic links of the invertebrate food web and disturbing the faunal community (Heong, 2009). However, insecticide use is very low in deepwater rice: less than $1 \%$ of 400 farmers questioned in the surveys used insecticide, and then applied only a single treatment (Catling, 1980).

\section{Faunal diversity}

Rice insect fauna is remarkably rich and uniform throughout the tropics in South and Southeast Asia and shows a unique natural stability (Islam et al., 2012). No other widely grown crop has 'this continuity of year round growth stages and favourable climate'. Invertebrates have diverse functions in the rice agroecosystem that include: phytophagy, predation and parasitism, disease vectoring, pollination, and the decomposition of plant and animal matter which assists in pest regulation, nutrient cycling and soil improvement. In several studies of rice ecosystems, arthropods made up more than $95 \%$ of the invertebrates, and insects were predominant.

Most previous studies of the fauna of Asian tropical rice were confined to irrigated rice. For example, Barrion and Litsinger (1982) collected 91 species of aquatic invertebrates on the IRRI farm of which $80 \%$ were insects, $10 \%$ crustaceans, and the rest were arachnids, molluscs and annelids. In subsequent studies where a suction sampler was also employed, the numbers of arthropods increased considerably, probably because the smaller forms in the neuston and lower plant canopy were more effectively sampled. Studies by Settle (1996) and Raspusas (2006), using both suction sampler and sweeps, caught more than 700 species in rice fields. 
In the present study the numbers of invertebrates identified to species and divided into four guilds totaled 333: $139(41.7 \%)$ phytophages, $75(22.5 \%)$ predators, $75(22.5 \%)$ parasitoids and $44(13.2 \%)$ scavengers (Tables $2,4,5,6)$. Table 7 shows that when all forms are considered, adding those identified to family/subfamily only, the total is increased to 375 invertebrates. The Insecta with 354 species were totally dominant, comprising $94 \%$ of all invertebrates and belonging to more than a hundred families. This is a conservative estimate since the fauna living in the benthos, neuston and lower rice canopy was not effectively sampled and many species were undoubtedly missed. Sweepnetting, the main collecting method, is not effective for sampling invertebrates: (i) at ground level (before flooding) and in the lower rice canopy, especially when plants are taller than $30 \mathrm{~cm}$, (ii) in contact with the water surface (the neuston) such as Collembola, predacious Heteroptera (Veliidae, Hydrometridae, Gerridae), and some spiders, (iii) benthic forms, especially the burrowers, such as Ephemeroptera and Odonata nymphs, chironomid larvae and tubificid worms, (iv) small aquatic invertebrates such as Protozoa, Rotifera and Crustacea, and (v) small, delicate, easily damaged insects found in the rice canopy, such as the Phoridae and Agromyzidae. Moreover, nocturnal forms (spiders, some beetles) were not sampled, apart from those attracted to light at Agrakhola, and those susceptible to pitfall traps such as carabid beetles.

In a subsequent study of an irrigated boro-transplant aman cropping system at Manikganj and Bogra (Islam et al., 2003), where flooding during the monsoon remained at around $30 \mathrm{~cm}$ in most fields but reached $50-60 \mathrm{~cm}$ is some, arthropods were collected with a suction sampling machine. This study identified 355 arthropods classified as 124 plant feeders, 118 predators and 113 parasitoids (none were classified as scavengers). At Manikganj and Bogra, more parasitoids and predators were recorded, and there were 36 spider species compared with only 7 in the 1977-79 deepwater rice study, indicating that many Arachnida were probably missed in the neuston of deepwater rice fields. The Manikganj study also caught Gerridae, Hydrometridae and large numbers of Mesovelia vittigera, whereas the 1977-79 study recorded none of these typical families living in the neuston. In another study of aquatic fauna by Das et al (1988; and unpublished) in several deepwater rice fields in West Bengal (on the Ganges floodplain only $150 \mathrm{~km}$ from deepwater rice in southern Bangladesh), seven Protozoa, eight Rotifera and 24 Crustacea were recorded.

A suction sampler is clearly more effective than a sweepnet for collecting small arthropods, especially those living in the neuston; but suction is not effective for larger Hymenoptera. In deepwater rice a combination of sweepnetting and the rearing of parasitoids (from their hosts) is superior to using a suction sampler alone.

\section{Seasonal fluctuation of fauna}

A number of factors governed the numbers and composition of the deepwater rice flora and fauna, the most important being the nature of the rice plant and the hydrological conditions. Floating rice possesses several characteristics that are lacking or only weakly developed in other rice cultural types and which strongly affect the bionomics of its associated fauna. (i) The growth duration of floating rice of 180-200 days compares with 100-125 days field duration for transplant aman, a difference of nearly $3 \mathrm{mo}$. Thus the rice habitat is extended for a longer period and there is time for at least one to two additional field generation for many insects. (ii) An extended vegetative phase of 2-2.5 mo from mid June to mid or end of August when the deepwater rice plants are elongating and producing new leaves and succulent stems. Such growth is favourable for some insects, while the developmental stages of others are lost beneath the water. (iii) Deepwater rice stems have less lignified tissue, 
many small air spaces and a massive lumen (internal cavity), all of which favour those insects boring into the stem. (iv) The large emersed biomass of deepwater rice supports a diverse variety of algae, some of which are nitrogen-fixing (Catling et al., 1981). Many of the fauna in the deepwater rice community are algal feeders. The numbers and composition of the biota fluctuate according to the changing floodwater conditions of the deepwater rice agroecosystem, and there is a definite seasonal succession of dominant flora and fauna.

\section{Preflood}

During land preparation the vegetation and crop residues are either worked into the soil, burnt or removed from the field. Cultivation practices and hand weeding severely reduces the plant stand and disrupts the biota. Young rice plants and weeds competing with the crop (diverse grasses, sedges and broadleaved plants), are subjected to varying degrees of drought stress for 2-3 months until flood inundation.

Phytophagous insects were active in the young rice plants at low population densities. Many spiders and other predators probably survived land preparation and moved to rice plants soon after germination or transplanting (Islam and Heong, 1999). The preflood period was conducive to moderate buildups of some canopy-living insects but their numbers are limited by the synchronous planting of large areas, the short growth period, the sparse rice stands and poor plant condition, and robust weeding practices.

\section{Flooding}

The fauna of deepwater rice and adjoining lowland fields was similar until flood inundation, many species moving between the different rice crops, sometimes in quite large numbers. The abrupt change to deep flooding (water level rising an average of 5-8 cm/day in the first three weeks and 2-6 cm/day in the second three weeks) profoundly affects the composition, population structure, and density of the fauna. The first flooding surge drastically reduces much of the non-rice flora but aquatic plants. quickly occupied the empty spaces. With inundation, epibenthic organisms dominate for a short while. Aquatic fauna is adapted to depleted oxygen conditions either by breathing air at the surface, or by possessing special breathing organs or gills. Many forms, such as dipterous larvae, live in the highly oxygenated neuston. Diving insects and some lycosid spiders carry air bubbles beneath the surface, while other insects pierce the stems of plants to breathe from the aerenchyma.

For many fauna the typical population buildups of the preflood period were suddenly arrested with deep flooding and numbers declined sharply. This is probably because the preferred feeding area of non-aquatic, phytophagous insects is submerged (as with planthoppers), and eggs laid in the leaf tissue (tettigonids, thrips) and sessile immature stages (mealy bugs) are drowned. Heavy monsoon rain also dislodges some forms (thrips). In general, arthropods show three basic types of fluctuation pattern as a response to deep flooding.

\section{(i) Activity declining sharply to remain at low levels}

This pattern applied to 16 species of leafhoppers and planthoppers, five leafeaters and three major predators. Populations crash precipitously with flooding and never return to preflood densities (Figure 3 and Table 3). In some sweeps taken immediately after the first surge of flooding, no hoppers were caught at all, and no hoppers were observed in the field observations. Similarly, with the exception of whorl maggot and grasshoppers, the activity 
of all major leafeaters was curtailed, as were populations of three predators. The decline in host numbers at this time also affect many predators.

\section{(ii) Activity continuing at moderate levels}

This pattern applied to fauna that are better adapted to deeply flooded conditions: acridids, whorl maggot, green leafhopper (Nephotettix virescens) and damselflies (Figure 4, Table 3). It includes those species that live in the upper canopy (leafhoppers), are active on the neuston (Collembola, some Homoptera), or possess definite aquatic adaptations (Oxya spp.). More than 50 species living in the plant canopy have aquatic larvae or nymphs, and at least 17 species are aquatic in all stages. Oxya spp., the dominant acridids, oviposit above the water level, and the nymphs are semi-aquatic with legs adapted for swimming.
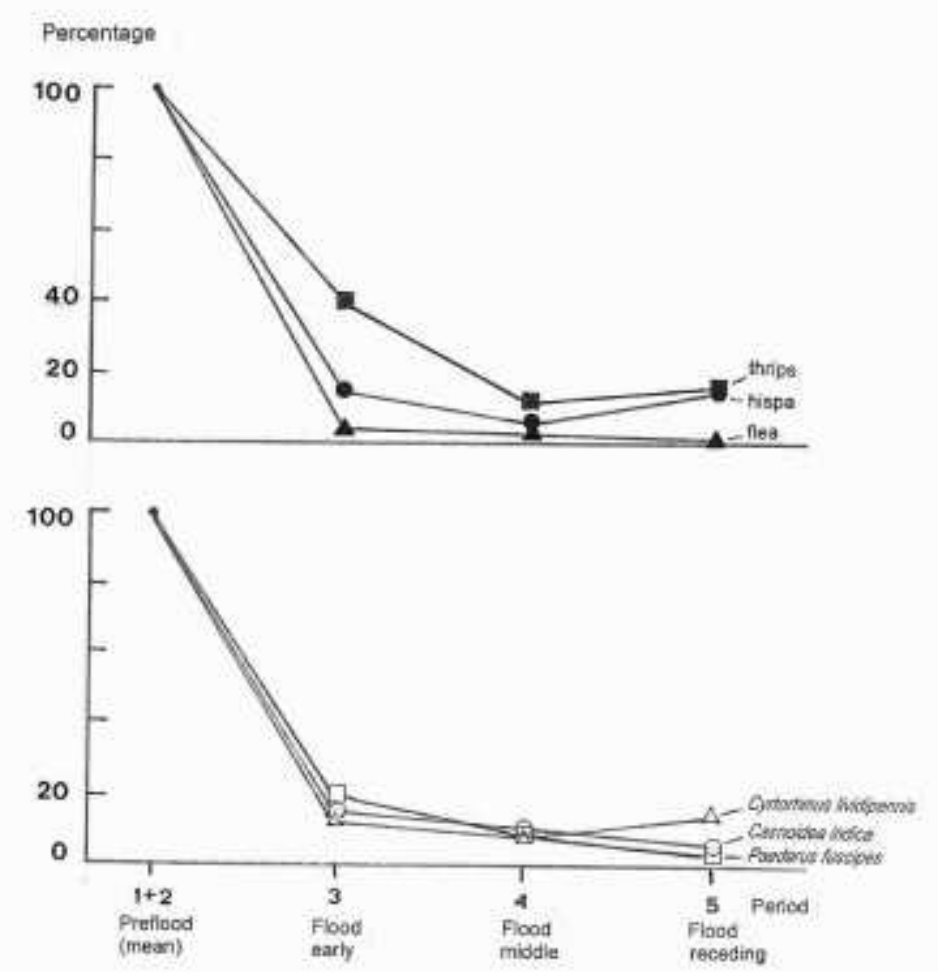

Fig. 3. Selected insects whose activity declines sharply with deep flooding; plotted as a percentage of mean numbers recorded during the preflood period. Drawn from data shown in Table 3. 


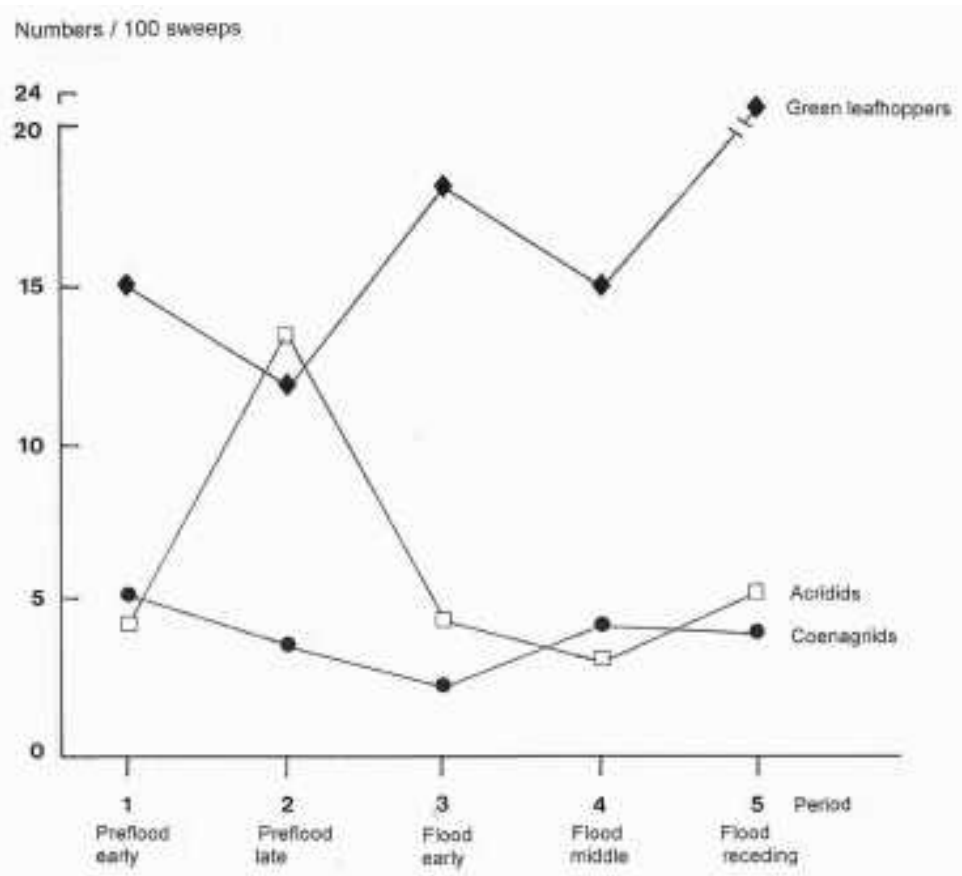

Fig. 4. Selected insects whose activity continues at moderate levels with deep flooding. Drawn from data shown in Table 3 and from Catling (1980).

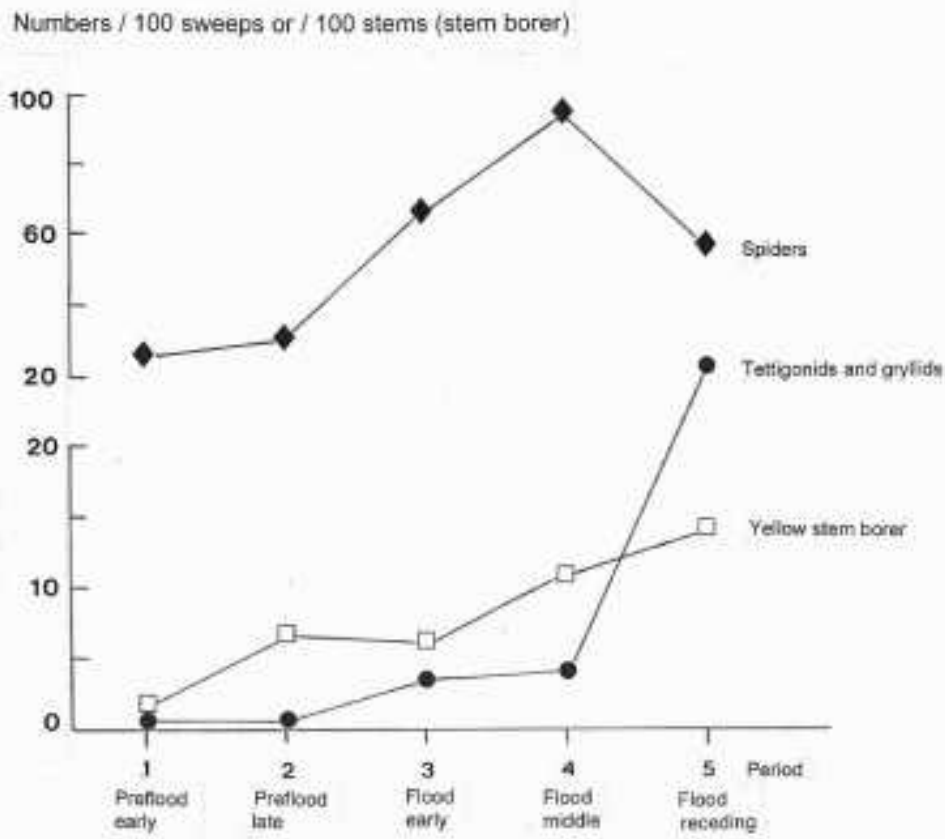

Fig. 5. Selected arthropods whose activity increases during deep flooding. Drawn from data shown in Table 3, Figure 2 and from Catling et al (1984-85).

(iii) Activity increasing

A few arthropods increased in numbers despite rising floodwater and rapid stem elongation. The activity of tettigonids, gryllids and the spider complex increased steadily from June to October (Figure 5, Table 3). The spider complex is clearly adapted to flooded deepwater rice. Yellow stem borer is highly adapted to deeply flooded rice: the succulent stems and leaves favour larval penetration; the larvae are able to live and feed inside the 
submerged stem and the adult emerges through the water; and milder weather extremes assist egg hatch and emergent neonates. Postflood and dry season. Insects such as rice seed bugs, tettigonids, Lygaeidae and Coreidae, feed on the developing panicles, while coccinellids are pollen feeders. The numbers of most other insects decline as the rice plant matures and senesces. After harvest the fields either remain fallow or are planted to dry season rabi crops. Most deepwater rice areas dry up at the end of the season and the crop residues, aquatic weeds and algal populations decompose. The vegetation is then increasingly subjected to drought stress as the soil dries and cracks, all organisms having to overcome a 3-4 mo harsh dry period.

Few of the aquatic fauna, most of them having a strong seasonal rhythm and special dry season behaviour breed continuously even when water is not available. Cladocera, Ostracoda and Rotifera produce 'winter eggs', while protozoans, annelids, copepods and nematodes make cysts. Crabs, lycosid spiders, some beetles and molluscs bury themselves in the soil or enter soil cracks to aestivate. Yellow and pink stem borers diapause in the rice stubble, while many rice insects simply move from deepwater rice to irrigated rice or grasses. Many plants perennate by producing resting propagules, dormant seeds or spores, or persist in perennial waters.

\section{Natural enemies}

Natural enemies tend to be more diverse in traditional rice systems (Islam et al., 2012) such as deepwater rice. Of the more than 70 predators (Table 4), spiders were by far the most abundant predacious group in deepwater rice at all times. Their populations were at their highest during deep flooding and remained numerous even during periods of rapid water rise. Spiders are probably responsible for limiting the numbers of leaf- and planthoppers from August to October. More than 70 parasitoid species (Table 5) form part of the deepwater rice faunal community. Fifty parasitoid species were reared from 14 recognised rice pests, with parasitism rates exceeding $50 \%$ in some cases. This large complex of predators and parasitoids, comprising nearly $45 \%$ of all invertebrates identified in the study, undoubtedly assists in regulating the numbers of many phytophages in deepwater rice. Pest outbreaks may be expected if their action is relaxed or disrupted.

Table 7. Total numbers of invertebrate fauna identified to species and family/subfamily from deepwater rice, Bangladesh, 1977-80.

\begin{tabular}{|c|c|c|c|c|}
\hline \multirow[t]{2}{*}{ Taxon } & \multicolumn{2}{|c|}{ Identified to species (no.) } & \multirow{2}{*}{$\begin{array}{l}\text { Identified to } \\
\text { family (no.) }\end{array}$} & \multirow{2}{*}{$\begin{array}{l}\text { Total forms } \\
\text { (no.) }\end{array}$} \\
\hline & Total species & Total families & & \\
\hline \multicolumn{5}{|l|}{ Insecta } \\
\hline Collembola & . & 1 & 1 & 1 \\
\hline Ephemeroptera & . & 1 & 1 & 1 \\
\hline Odonata & 9 & 2 & . & 9 \\
\hline Orthoptera & 15 & 5 & 4 & 19 \\
\hline Dermaptera & 1 & 1 & . & 1 \\
\hline Dictyoptera & . & 1 & 1 & 1 \\
\hline Psocoptera & . & 1 & 1 & 1 \\
\hline \multicolumn{5}{|l|}{ Hemiptera: } \\
\hline Homoptera & 30 & 6 & 4 & 34 \\
\hline Heteroptera & 21 & 10 & 2 & 23 \\
\hline Thysanoptera & 5 & 2 & 1 & 6 \\
\hline Lepidoptera* & 26 & 6 & 1 & 27 \\
\hline Trichoptera & 1 & 1 & . & 1 \\
\hline
\end{tabular}




\begin{tabular}{l|c|c|c|c|}
\hline Diptera* & 33 & 28 & 7 & 40 \\
Hymenoptera & 67 & 18 & 12 & 79 \\
Coleoptera** & 99 & 18 & 11 & 110 \\
Strepsiptera & 1 & 1 & $\cdot$ & 1 \\
$\quad$ Total Insecta & $\mathbf{3 0 8}$ & $\mathbf{1 0 2}$ & $\mathbf{4 6}$ & $\mathbf{3 5 4}$ \\
Other invertebrates & 5 & - & 1 & 6 \\
\hline Nematoda & 2 & 2 & $\cdot$ & 2 \\
Crustacea & 7 & 5 &. & 7 \\
Arachnida: & 2 & 2 & $\cdot$ & 2 \\
$\quad$ Araneida & 4 & 4 & $\cdot$ & 4 \\
$\quad$ Acarina & $\mathbf{2 0}$ & $\mathbf{1 3}$ & $\mathbf{1}$ & $\mathbf{2 1}$ \\
Mollusca & 328 & 115 & 47 & 375 \\
\hline Total other invertebrates & & & \\
\hline Grand total & * Underestimated as large part of material not identified at all, or not to species level. & \\
** Includes some species taken in deepwater rice off-season only. &
\end{tabular}

\section{ACKNOWLEDGEMENTS}

We are grateful to the Bangladesh Rice Research Institute (BRRI), the Overseas Development Administration of the UK and the International Rice Research Institute for the opportunity to conduct the study. We also thank BRRI scientific assistants, especially Messrs M Yasin and S R Bhuiyan, for their exceptional field work. We are also indebted to a phalanx of specialists for identifying the fauna: Drs and Messrs Z Boucek, J D Bradley, M L Cox, I D Gauld, S K Ghauri, K M Harris, R B Madge, U Ramakrishnan, B R S Rao, J M Ritchi (British Museum, Natural History or Commonwealth Institute of Entomology, London); Dr H Nagaraja (Commonwealth Institute of Entomology, Banglaore); Dr N D Jago (Centre for Overseas Pest Research, London); Dr L Masner (Biosystematics Research Institute, Ottawa); Dr V K Gupta (University of Delhi); Dr Angoon Lewvanich (Department of Agriculture, Entomology and Zoology Division, Bangkok); Mr B Barrion (International Rice Research Institute).

\section{REFERENCES}

Barion, A T and J A Litsinger. 1982. The aquatic invertebrate fauna of IRRI rice fields. Paper presented at the $13^{\text {th }}$ National Conference of the Pest Control of the Philippines, May 5-8, Baguio City, Philippines. pp. 1-5.

Catling, H D. 1980. Deepwater rice in Bangladesh: A survey of its fauna with special reference to insect pests. Deepwater Rice Pest Management Project, Bangladesh Rice Research Institute and Overseas Development Administration of the UK. p. 100. (mimeo).

Catling, H D. 1992. Rice in deep water. International Rice Research Institute and Macmillan Press, London. p. 542.

Catling, H D and Z Islam. 1995. Studies on the ecology of the yellow stem borer, Scirpophaga incertulas (Walker) (Pyralidae), in deepwater rice in Bangladesh. Crop Prot., 14(1): 5767.

Catling, H D, M R Martinez and Z Islam. 1981. Survey of algae associated with deepwater rice in Bangladesh. Cryptogamie Algol., II(2): 109-121.

Catling, H D, Z Islam and R Pattrasudhi. 1984. Seasonal occurrence of the yellow stem borer, Scirpophaga incertulas (Walker) on deepwater rice in Bangladesh and Thailand. Agric. Ecosys. Environ., 12: 47-71. 
Cox, P G. 1980. Some New Approaches for Work on Ufra Disease of Deepwater Rice in Bangladesh. Report of Plant Pathologist. Bangladesh Rice Research Institute/Overseas Development Administration of the UK, Deepwater Rice Pest Management Project. p. 50. (mimeo).

Das, D N, B Roy, P K Mukhopadhyay, K Mitra and A C Nandy. 1988. Ecological studies of the aquatic environment of a large deepwater rice field at Peerapur in Hooghly District, West Bengal. In: Proceedings of the National Seminar on Management of Fisheries in Inland Openwater Systems of India. 14-16 December, Barrackpore, West Bengal, India. pp. 28-35.

Grist, D and R J A Lever. 1969. Pests of Rice. Longman, London. p. 520.

Heong, K L. 2009. Are planthopper problems caused by a breakdown in ecosystem services? p. 221-231. In: K L Heong and B Hardy (eds.) Planthoppers: New Threats to the Sustainability of Intensive Rice Production Systems in Asia. International Rice Research Institute, Asian Development Bank, and Australian Centre for International Agricultural Research, Philippines.

Islam, Z. 1989. Snail: An occasional pest of deepwater rice. Deepwater and Tidal Wetlands Rice, International Rice Research Institute. pp. 7-8.

Islam, Z and K L Heong. 1999. Effects of tillage on arthropod predators of rice insect pests in irrigated rice. In: Proceedings of the International Symposium on Integrated Pest Management in Rice-based Ecosystems. Zhongshan University. Guangzhou, P R China. pp. 198-208.

Islam, Z, K L Heong, D Catling, K. Kiritani. 2012. Invertebrates in Rice Production Systems: Status and Trends. Background Study Paper No. 62. Commission on Genetic Resources for Food and Agriculture. Food and Agriculture Organisation of the United Nations. p. 91.

Islam, Z, M A Rahman, A T Barrion, A Polaszek, T Chancellor, K L Heong, N Ahmed, M Haq and N Q Kamal. 2003. Diversity of arthropods in irrigated rice in Bangladesh. Bangladesh J. Entom., 13(2): 1-25.

Nartshuk, E P and Ding Yang. 2011. New data on grassflies of the family Chloropidae (Diptera) from Korea with analysis of the fauna composition. Far East Entomologist, 226: 1-11.

Rapusas, H R, J M Schiller, K L Heong, A T Barrion, V Sengsouulivong, S Inthavong and I Knthavong. 2006. Arthropod communities of the lowland rice ecosystems in the Lao PDR. In: J M Schiller, M B Chabnphengxay, B Linguist and S Apa Rao (eds.) Rice in Laos. International Rice Research Institute and Australian Centre for International Agricultural Research. p. 235-164.

Reissig, W H, E A Heinrichs, J A Litsinger, K Moody, L Fiedler, T W Mew and A T Barrion. 1986. Illustrated Guide to Integrated Pest Management in Rice in Tropical Asia. International Rice Research Institute, Manila, Philippines, p. 411.

Settle, W H, H Ariawan, E T Astuti, W Cahyana, A L Hakim, D Hindayana, A S Lestari and Pajarningsih. 1996. Managing tropical rice pests through conservation of generalist natural enemies and alternate prey. Ecology, 77(7): 1975-1988. 